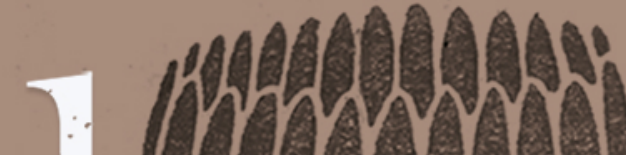

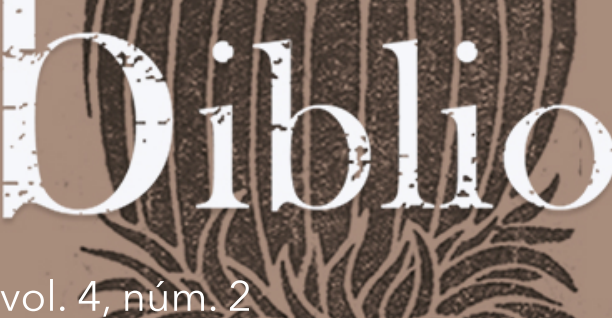

vol. 4, Aum?2

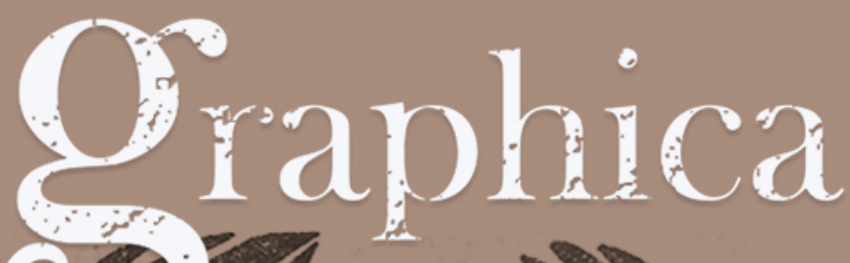

segubdo-semestre 2021 s.

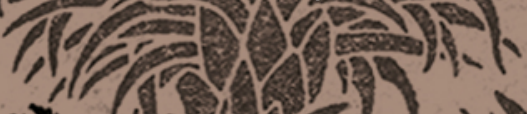
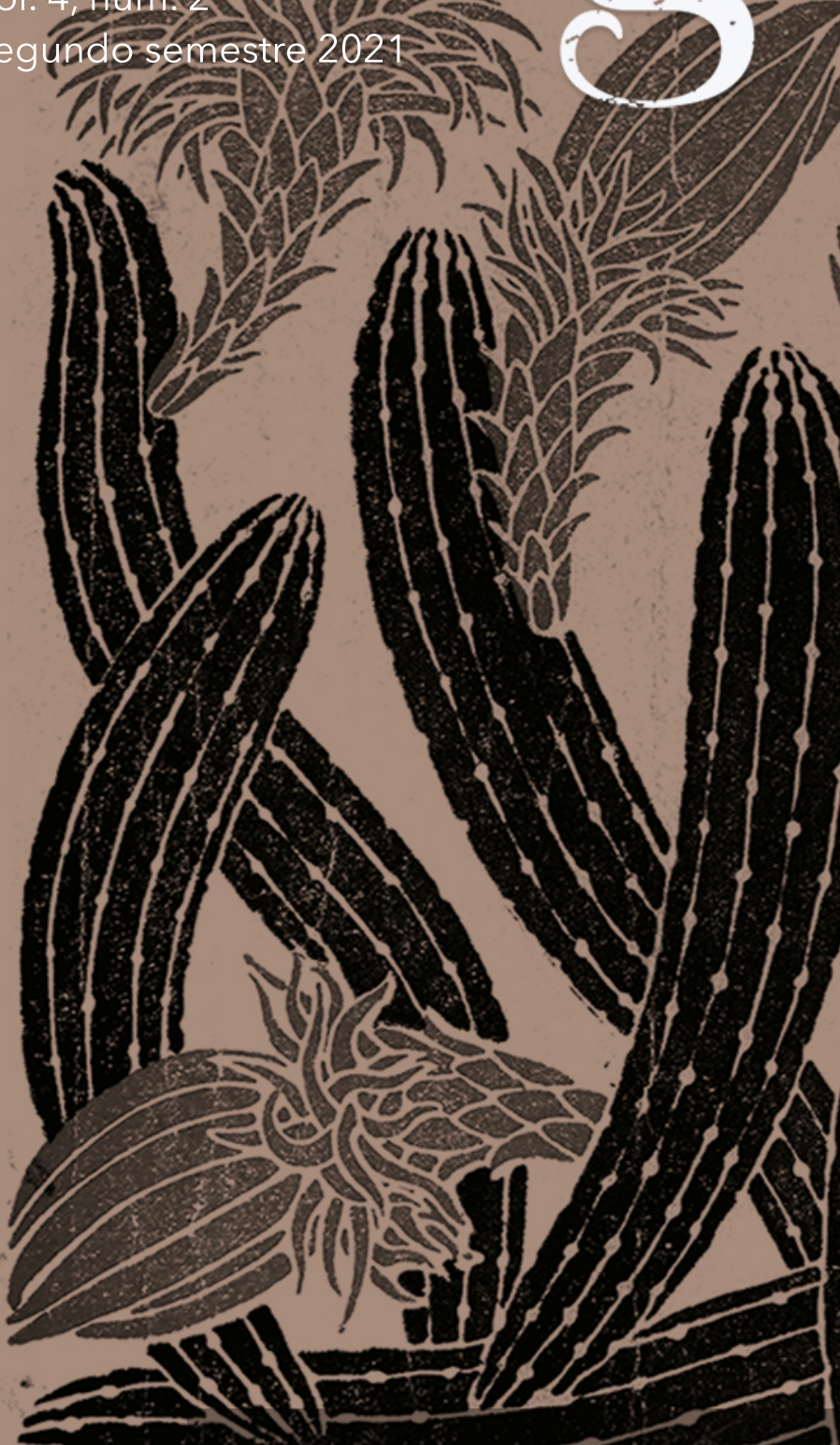

ISSN $2594-178 X$
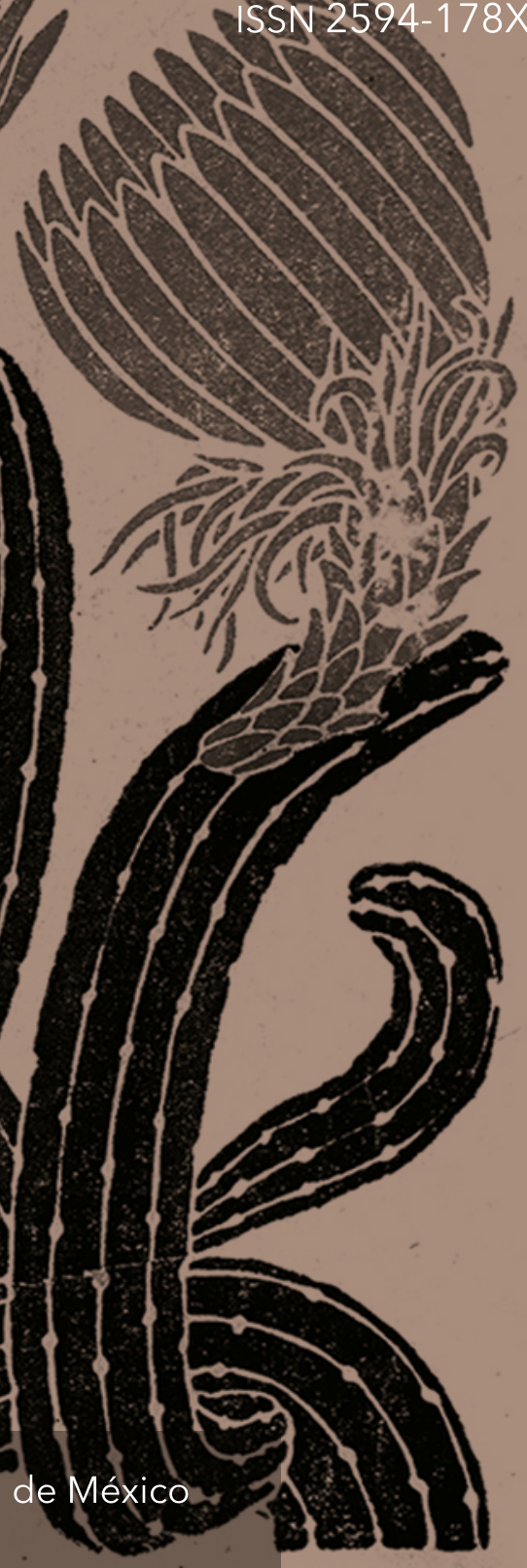


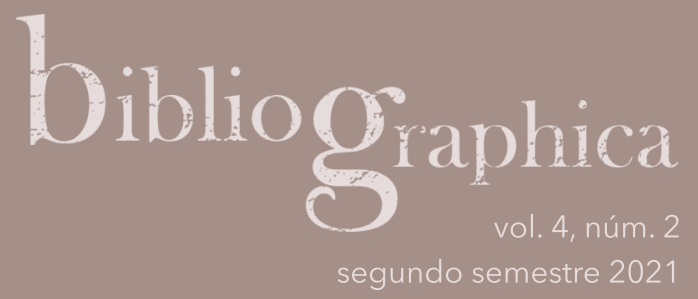

\section{El periodismo cultural español en México durante la Revolución: Ricardo de Alcázar y la revista Rojo y Gualda, 1916-1917}

Spanish Gultural Journalism in Mexico during the Revolution: Ricardo de Alcázar and the Magazine Rojo y Gualda, 1916-1917

\section{Alicia Gil Lázaro}

Universidad de Sevilla,

Departamento de Economía e Historia Económica,

Área de Historia e Instituciones Económicas,

Sevilla. España

agil3@us.es

ORCID: https://orcid.org/0000-0002-5217-5246

Recepción: 04.05.2021 / Aceptación: 10.06.2021

DoI: https://doi.org/10.22201/iib.2594178xe.2021.2.179 
Resumen

Palabras clave

Abstract

Keywords
Este texto analiza la primera etapa del semanario cultural Rojo y Gualda, fundado por Ricardo de Alcázar, Florisel, conocido periodista y escritor español radicado en Ciudad de México. Una larga tradición de periodismo español en este país le antecedía, y su aparición en marzo de 1916 rompió con el carácter beligerante e intervencionista mostrado por la prensa hecha por españoles en los primeros tiempos revolucionarios. Tras varios años de silencio, fue el primer intento exitoso de poner en marcha una nueva empresa periodística en el seno de la colonia española en México, de manera que -sin renunciar a los temas y modos caros al grupo al que iba dirigido- debió incluir ciertas reformas para sobrevivir en el hostil clima revolucionario y publicarse durante cuatro años y medio, hasta septiembre de 1920. Este artículo traza un perfil biográfico de Florisel, su editor los primeros 16 meses, y describe el contexto periodístico en el que apareció la revista, así como sus etapas, formato, secciones y géneros, los colaboradores y temas principales.

Periodismo español; revistas culturales; Rojo y Gualda; colonia española; México revolucionario.

This text analyzes the first stage of the cultural weekly Rojo y Gualda, founded by Ricardo de Alcázar, Florisel, a well-known Spanish journalist and writer based in Mexico City. A long tradition of Spanish journalism in Mexico preceded the establishment of this publication, whose appearance in March 1916 disrupted the belligerent and interventionist character of the Spanish press in the early revolutionary period. After several years of silence, this was the first successful attempt to launch a new journalistic enterprise within the Spanish colony in Mexico. However, without dismissing the topics and modes dear to the group it was intended for, the magazine had to make certain reforms to survive the hostile revolutionary climate and continue publishing for four and a half years until September 1920. This article traces a biographical profile of Florisel, editor of the weekly during the first 16 months, and describes the journalistic context where it appeared, as well as its format, stages, sections and genres, its contributors and main subjects.

Spanish journalism; cultural magazines; Rojo y Gualda; Spanish community; revolutionary Mexico. 


\section{Introducción ${ }^{1}$}

Junto a la creación de asociaciones étnicas, el periodismo constituyó uno de los canales más importantes de articulación de la identidad nacional entre los españoles emigrados al continente americano en el tiempo de la gran oleada migratoria (ca. 1880-1930). La prensa informativa, las revistas de carácter cultural o los órganos de comunicación de las asociaciones, entre otros, se convirtieron en ámbitos privilegiados desde los cuales se podía "construir identidad patriótica en la diáspora", de acuerdo con Marcela García Sebastiani. ${ }^{2}$

La colonia española radicada en México alentó diferentes iniciativas periodísticas desde la segunda mitad del siglo XIX y buena parte del XX, que perseguían reforzar la cohesión identitaria y, sobre todo, legitimar la organización institucional comunitaria. Al igual que en otras latitudes americanas receptoras de inmigración española, la producción intelectual de esa comunidad sivió para presentar adecuadamente argumentos con el fin de negociar los términos de la integración en la sociedad de acogida sin una total asimilación y también para obtener el reconocimiento moral y político de España y su tradición cultural de cara al exterior. ${ }^{3}$

La historiografía mexicana ha fijado la atención en el periodismo "étnico" español de la segunda mitad del siglo XIX, identificándolo con una "tradición periodística, empresarial, literaria y editorial" fecunda y compleja, en palabras de Pablo Mora, ${ }^{4}$ orientada a establecer lazos culturales entre las dos naciones.

\footnotetext{
${ }_{1}^{1}$ Adscrita al Instituto Universitario de Estudios sobre América Latina (IEAL) de la Universidad de Sevilla. Este estudio ha sido posible gracias a una estancia de investigación realizada en febrero de 2019 en la Biblioteca Nacional de México, y fue subvencionado por el equipo de investigación HAR2015-64494-R: "La prensa de la emigración española: acción cultural, patriotismo y recreación identitaria. Estudios de caso en Argentina, Cuba, México y Uruguay, 1870-1960". La autora agradece al personal de la BNM su amable atención, y al equipo de investigación todo el apoyo prestado para su realización.

${ }^{2}$ Marcela García Sebastiani, "Nacionalismos e identidad nacional entre los españoles en Argentina", en Hacer patria lejos de casa. Nacionalismo español, migración y exilio en Europa y América (1870-2010), ed. de Marcela García Sebastiani y Xosé M. Núñez Seixas (Zaragoza: Prensas Universitarias, 2020), 42.

${ }^{3}$ Concepción Navarro Azcue y Gustavo H. Prado, eds., Intellectualism and Migration. International Networks of Europeans Culture in America (19th - 21st Centuries) (Charleston: Global South, 2016); Concepción Navarro Azcue y Julio Mesa Yanes, "Dossier: prensa y emigración española en América", Revista Internacional de Historia de la Comunicación 12 (2019): 8-15, DOI: 10.12795/RiHC. 2019.i12.01.

${ }^{4}$ Pablo Mora, "Presentación [s. XIX]" a Españoles en el periodismo mexicano, siglos XIX y XX, comp. y ed. de Pablo Mora y Ángel Miquel (México: UNAM, IIB / UAEM / Fundación Carolina, 2008), 15.
} 
Se pueden citar más de una veintena de publicaciones periódicas españolas editadas antes de $1910 .{ }^{5}$ Asimismo, existe una amplia investigación acerca del ejercicio periodístico desarrollado por exiliados españoles en este país a partir de la década de 1940, ya que la llegada de escritores e intelectuales republicanos tras la guerra civil tuvo un impacto fuerte no sólo en la prensa de la colonia española, sino en la vida cultural e intelectual de México. ${ }^{6}$

Se podría hablar, pues, de dos "edades de oro" del periodismo español en México, como campos de investigación clásicos en los estudios que analizan las relaciones entre ambos países. Frente a esto, los años revolucionarios y posrevolucionarios habrían sido un tiempo "bisagra" entre dos grandes épocas, marcado por la conflictividad política, el repliegue económico y la dificultad de llevar a cabo proyectos periodísticos propios de largo aliento.

La escasa prensa española que vio la luz en esas décadas estuvo, en palabras de Ángel Miquel, "constantemente aquejada por la inestabilidad de las pequeñas empresas que la constituían, que cambiaban con frecuencia de dueño, director y redacción", y se ha definido, en general, como una prolongación de la prensa desarrollada en las últimas décadas del siglo XIX. La producción del exilio, según este autor, fue más relevante "por su cantidad y calidad" para la historia cultural reciente, por lo que claramente este hecho parece haber opacado el periodismo de los primeros cuarenta años del siglo. ${ }^{7}$ Sin embargo, el propio

${ }^{5}$ Armando de Maria y Campos, Reseña histórica del periodismo español en México, 1821 1932 (México: Cía. Editora, Distribuidora de Ediciones, S. A., 1960); Pablo Mora y Ángel Miquel, eds., Españoles en el periodismo mexicano. Entre las principales publicaciones destacan: La Iberia (1867-1876), La Colonia Española (1873-1879), El Centinela Español (1879-1882) y El Pabellón Español (1883-1890). En la primera década del siglo XX aparecieron La Nación Española, Correspondencia de España y El Diario Español. Véase Mar Gutiérrez Domínguez, "Tensiones y conflictos entre los españoles en la Ciudad de México. Negocios, política, prensa y sociedad (1867-1914)" (tesis de doctorado, El Colegio de México, 2021).

${ }^{6}$ Ana González Neira, Prensa del exilio republicano, 1936-1977 (Santiago de Compostela: Andavira Editora, 2012); Juan Carlos Sánchez Illán, dir., Diccionario biográfico del exilio español de 1939: los periodistas (Madrid: FCE, Cátedra del Exilio, 2011); María M. Ordóñez Alonso, "El exilio republicano español y su aportación a la prensa y periodismo en México", Laberintos: Revista de Estudios sobre los Exilios Culturales Españoles, núm. 13 (2011): 113122. Francisco Caudet, El exilio republicano en México. Las revistas literarias (1939-1971) (Madrid: Fundación Banco Exterior, 1992).

7 Ángel Miquel, "Presentación [s. XX]" a Españoles en el periodismo mexicano, 196. Como ejemplo del desinterés hacia el periodo, en el coloquio efectuado en la Biblioteca Nacional de México, en agosto de 2005, que motivó la publicación citada, no se presentó ninguna ponencia relativa a las primeras décadas del siglo XX. 
Miquel reconoce que en esta borrosa etapa se desmarcaron varios periodistas y empresas culturales que merecen "una revalorización". Entre ellos se halla justamente el escritor Ricardo de Alcázar (1884-1950) y la revista Rojo y Gualda.

El presente texto aborda la reanudación del periodismo hecho por españoles tras el triunfo de Venustiano Carranza y la gradual normalización de la vida política mexicana, una vez finalizada la fase más violenta del conflicto civil. El triunfo revolucionario obligó a las iniciativas periodísticas españolas de la segunda mitad de la década de 1910 a moderar su tono y tratar de atenuar cualquier expresión política pública contraria a los nuevos detentadores del poder, rompiendo en buena medida con el carácter beligerante que había mostrado el periodismo español en el tiempo inmediatamente anterior, sobre todo su principal cabecera, El Correo Español. ${ }^{8}$

Así, tras un corto periodo en silencio, la creación de la revista cultural Rojo y Gualda constituyó el primer intento exitoso de poner en pie una nueva empresa periodística en el seno de la colonia española de México, de manera que, sin renunciar a los temas y modos caros al grupo al que iba dirigido ni a la larga tradición que le precedía en estas lides, el semanario debió adoptar un tono más morigerado y neutral con el cual sobrevivir en el hostil clima político de la década de $1910 .^{9}$

8 Josefina MacGregor, Revolución y diplomacia: México y España, 1913-1917 (México: INEHRM, 2002): 68. Lydia Elizalde, El Correo Español. Aportes a la prensa periódica en México (1889-1898) (México: Bonilla Artigas editores, 2016). El diario era el principal órgano de expresión de los españoles hacia 1910. Había sido fundado por Luis Juliet Elizalde en 1889. En 1902 lo compró José Porrúa, quien fue su editor hasta 1911. Tras la salida de Porrúa, El Correo pasó por diferentes manos hasta que en 1913 se hizo cargo de la edición el periodista español Lorenzo B. Serrano (que firmaba con el pseudónimo Constant Leroy, según Armando de Maria y Campos, Reseña histórica, 96). Hasta ese momento el diario había expresado veladamente su oposición a Madero, pero con Serrano las simpatías hacia el huertismo se hicieron explícitas, lo que llevó a su clausura a finales de 1914 y a la expulsión del país de su director.

${ }_{9}^{9}$ No aparecen apenas en sus páginas comentarios críticos abiertos sobre la política nacional o los jefes revolucionarios. El tratamiento dado a la figura presidencial, los militares norteños o la nueva situación del país fue escaso y, en general, laudatorio. "La revolución mexicana juzgada en el extranjero, la figura del general Pablo González", Rojo y Gualda, año I, núm. 22 (16 de septiembre de 1916). También se optó por hacer descansar las opiniones sobre México publicadas en la revista en la voz de reputados mexicanos, como Juan Sánchez Azcona, en su papel de diplomático: "La situación de Méjico", ibid., núm. 36 (23 de diciembre de 1916). "El ministro de México en Europa expone a los lectores de El Liberal, de Madrid, la verdadera situación de esta República". El periodista español Andrés Peláez Cueto salió en defensa de los españoles durante la crisis de subsistencia en la 
El periodista español Ricardo de Alcázar, su fundador, estuvo al frente hasta julio de $1917 .{ }^{10}$ En ese tiempo la revista adquirió un perfil intelectual propio, marcado por sus preferencias estéticas, estrechamente conectadas a las corrientes culturales que fluían entre ambas orillas del Atlántico. En estas páginas se analiza esa primera etapa y para ello se ofrece previamente un perfil biográfico de su editor y del contexto periodístico e histórico en el que apareció la revista. Tras esto, la atención se dirige a sus características, etapas y colaboradores, así como a los principales contenidos, con objeto de contrastar una idea tradicional y enraizada en la historiografía de que el periodismo español de esta época se mantuvo simplemente "en terrenos tales como los de la crónica de espectáculos o las actividades de beneficencia, el desarrollo empresarial y la vida social de la comunidad hispana". ${ }^{11}$

Por el contrario, la hipótesis de este artículo es que el semanario Rojo y Gualda que De Alcázar editó trascendió ampliamente esos propósitos, configurándose como un ejemplo claro de revista cultural hecha por periodistas emigrados que sin duda conocían bien el panorama intelectual de la península y cuya principal vocación editorial fue procurar acercar la producción literaria y ensayística española al contexto cultural mexicano, a través de un énfasis en la historia, las letras y la actualidad del país de origen. Constituyó un medio para reafirmar la identidad hispana en la emigración, al mismo tiempo que, cómo no, trataba de servir a los intereses de su público lector, la colonia española.

\section{Ricardo de Alcázar, Florisel. Inmigrante y periodista}

Wenceslao Rodríguez llegó a Veracruz en 1898 con 14 años procedente de Luarca, una aldea de la costa occidental asturiana. En el puerto se dedicó al oficio de tabaquero, pero no lo ejerció durante mucho tiempo, pues en pocos años logró dedicarse a las letras, como periodista en diarios locales -por ejemplo,

capital mexicana: "La carestía de las subsistencias", ibid., núm. 6 (29 de abril de 1916). De Alcázar incluyó un reportaje sobre la gala celebrada en el Teatro Principal, a la que asistió el presidente de la república, Venustiano Carranza, organizada por la Unión Española, ibid., año II, núm. 45 (24 de febrero de 1917).

${ }^{10}$ Se ha presentado, erróneamente, a Alfonso Camín como fundador de la revista. Véase Albino Suárez, "Alfonso Camín, Asturias y España: centenario de su nacimiento", Boletín del Instituto de Estudios Asturianos 45, núm. 137 (1991): 256; Alicia Gil Lázaro, "Prensa étnica e inmigración. El periodismo español en México en el primer tercio del siglo XX", Revista Internacional de Historia de la Comunicación, núm. 9 (2017): 51.

${ }^{11}$ Mora, "Presentación" a Españoles en el periodismo mexicano, 16-17. 
El Dictamen o La Opinión-, y también empezó a ser conocido como escritor y poeta. ${ }^{12}$ A principios de 1913 se trasladó a Ciudad de México y, salvo breves paréntesis fuera de la capital y un viaje a España, en ella transcurrió su vida, hasta su fallecimiento en $1950 .{ }^{13}$

Se dio a conocer por dos de sus pseudónimos: Ricardo de Alcázar y Florisel, que aquí utilizamos indistintamente, aunque no fueron los únicos: dado a los sobrenombres, firmó sus escritos con otros más, como el muy quijotesco Ginesillo de Pasamonte, por el que se dio a conocer en Veracruz. ${ }^{14}$

Su carácter autodidacta y emprendedor, junto a su habilidad para escribir, le permitieron impulsar diversos proyectos editoriales a lo largo de su carrera. El primero fue la revista Gente Nueva, editada cuando todavía se hallaba en el puerto, 13 años después de su llegada, junto a otro inmigrante asturiano, Ceferino Martínez Riestra. ${ }^{15}$

A su llegada a la capital, la comunidad española sumaba poco más de 12 mil integrantes, el tamaño máximo alcanzado hasta entonces. La cifra suponía casi la mitad del total de españoles llegados al país y la mitad de los extranjeros residentes en la ciudad. A pesar de integrar en su seno un número relativamente alto de empresarios y terratenientes, el grueso del grupo se componía de jóvenes empleados o dependientes de comercio, probablemente con pocos afanes ilustrados y escaso tiempo para leer prensa. ${ }^{16}$

12 Juan José Bada, Ricardo de Alcázar (Florisel). Bosquejo biográfico y crítico (México: s. p. i., 1951), 13-21. Según este biógrafo, Florisel llegó a Veracruz recomendado por uno de los dueños de la fábrica de puros "Balsa Hnos." y "no sirviendo para cualquier cosa, le nombraron lector de los obreros". Véase también el artículo "Florisel. Un treviense ilustre en el Casino Español", Casino Español de México. Boletín Informativo 10 (2005): 21. La aldea de procedencia del escritor es Villanueva de Trevías.

${ }^{13}$ Bada, Ricardo de Alcázar, 12. "Llevaba en México, casi lo que va de siglo, de donde no se ausentó más tiempo que unos meses con motivo de un viaje que hizo a España en calidad de relator en la 'Comisión de Reclamaciones' designada por la Embajada de España y presidida por el Cónsul de Puebla, Carlos Badía".

${ }_{14}$ Ibid., 21.

15 José Ignacio Gracia Noriega, "Ceferino Martínez Riestra: un escritor", entrevista, acceso el 30 de abril de 2021, http://www.llanes.as/nor/nie/20021014.htm. También le siguió en su traslado posterior a Ciudad de México y en su inserción en los medios de prensa capitalinos.

${ }^{16}$ Agustín Sánchez Andrés y Pedro Pérez Herrero, eds., Historia de las relaciones entre España y México, 1821-2014 (Madrid: Marcial Pons / Universidad de Alcalá, Instituto de Estudios Latinoamericanos, 2015), 114, 134-136. Lorenzo Meyer, El cactus y el olivo. Las relaciones de México y España en el siglo XX. Una apuesta equivocada (México: Océano, 2001), 74-80. 
Un diplomático español en México afirmaba en 1904 que ese "elemento español" en México, "tan satisfecho de sí mismo", se distinguía por su laboriosidad y riqueza, pero no "por su cultura ni por su erudición". ${ }^{17}$ En otra ocasión, en 1913, el Consulado respondía a un magnate español de la prensa, quien solicitaba un listado de domicilios de la colonia allí residente, con el fin de aumentar la nómina de suscriptores a su diario. El cónsul le enviaba una "nota de los Centros españoles, y de los compatriotas más caracterizados", pero no así de los inscritos en el registro consular, por ser "en su mayoría empleados y gente trabajadora que seguramente no ha de responder a los planes de usted". ${ }^{18}$

El periodismo de la colonia española hasta entonces había sido auspiciado por las corporaciones del grupo, como el Casino Español o la Cámara de Comercio (La Iberia de Anselmo de la Portilla o El Correo Español, en la etapa previa a José Porrúa). ${ }^{19}$ Más frecuentemente dependía de la iniciativa privada de los propios editores o del patrocinio de algunos hombres fuertes del grupo, bajo cuyo liderazgo y financiación se editaban los diarios. ${ }^{20}$ Aunque hay pocas referencias sobre las tiradas o el número de suscriptores, en principio todo parece indicar que tanto el sistema de suscripciones como la introducción gradual de la publicidad de los establecimientos comerciales del grupo permitieron mantener la actividad, a menudo en un precario equilibrio no exento de quiebras. ${ }^{21}$

En todo caso, a pesar de ser una labor orientada hacia un núcleo relativamente pequeño de compatriotas, su utilidad rebasaba el estrecho marco de los lectores habituales de la colonia, para adquirir el carácter de representación letrada del grupo frente a la sociedad mexicana, en concreto sus élites sociales y culturales. Por ello, los criterios mercantiles no debieron ser tan influyentes en la decisión de apoyar económicamente una iniciativa de este carácter, como sí

\footnotetext{
${ }^{17}$ Archivo del Ministerio de Asuntos Exteriores, Legación de España en México, 25-VI1904, en Meyer, El cactus y el olivo, 81.

${ }^{18}$ Archivo General de la Administración, Consulado de España en México, caja 9652, el cónsul de España Emilio Moreno Rosales a Torcuato Luca de Tena, a 19-VI-1913, en Alicia Gil Lázaro, Inmigración y retorno. Españoles en la Ciudad de México, 1900-1936 (Madrid: Marcial Pons / Universidad de Alcalá, Instituto de Estudios Latinoamericanos, 2015), 283.

19 Adriana Gutiérrez Hernández, "Anselmo de la Portilla, La Iberia y el Casino Español (1867-1876)", en Españoles en el periodismo mexicano, 77-89; Aurora Cano Andaluz, Historia de la Cámara Española de Comercio en México (México: Santillana, 2009), 92.

${ }^{20}$ Pablo Mora, "Telesforo García: articulista y polemista en El Centinela Español", en Españoles en el periodismo mexicano, 123-128.

${ }^{21}$ Gutiérrez Hernández, "Anselmo de la Portilla...", 85.
} 
lo fue el objetivo de recrear una imagen exterior de la colonia, alejada de los estereotipos circulantes en la época. ${ }^{22}$

La Revolución acabó con la estabilidad social y el estatus político que había gozado el grupo hasta entonces y la oleada de violencia desatada por los bandos contendientes afectó a los medios de comunicación escritos de los españoles, ya frágiles de por sí. Sin embargo, y contra todo pronóstico, el periodismo étnico español no llegó a desaparecer. En la segunda mitad de la década de 1910 nacieron varias iniciativas impulsadas por una generación de escritores y periodistas expatriados desde finales del siglo XIX y los primeros años del XX, dentro de la cual De Alcázar fue adquiriendo cierta notoriedad junto a otros personajes como Julio Sesto, Alfonso Camín, Francisco Martínez de Bujanda, Ceferino Martínez Riestra, Felipe Velasco, Baltasar Fernández del Cue, Desiderio Marcos, Enrique Guardiola Cardellach, Andrés Peláez Cueto, José Albuerne, Alberto Barella y Humberto Rivas Panedas.

Parece que sus nexos con la vieja escuela de periodistas españoles porfirianos fueron frecuentes; los recién llegados tomaron contacto con los medios existentes y sus editores, y en muchos casos comenzaron trabajando para ellos. Aunque la Revolución tuvo un efecto de parteaguas generacional entre ellos, el recambio se produjo de forma gradual -Telésforo García o Enrique de Olavarría y Ferrari, por ejemplo, murieron en 1918, pero en los años previos el primero colaboraría varias veces en Rojo y Gualda. ${ }^{23}$

El formato de prensa diaria fue abandonado temporalmente y el periodismo español se refugió bajo el paraguas de la cultura y la forma de revistas semanales, quincenales o mensuales. Algunas de las creadas en esa época fueron: $E I$ Otro Mundo (1915), Rojo y Gualda (1916-1920), Iberia. Revista Mensual Española (1917-1918), Castillos y Leones (1920-1921), Don Quijote (1920-1922), Tricolor. Una Revista Mexicana de Cultura (1917-1932), Revista Española (1922-1926), La Voz Nueva (1927-1931) y El Espectador (1930). ${ }^{24}$ Con una nómina de lectores tan

\footnotetext{
22 Ángel Miquel, Jesús Nieto Sotelo y Tomás Pérez Vejo, comps., Imágenes cruzadas. México y España, siglos XIX y XX (México: UAEM, 2005); Agustín Sánchez Andrés, Tomás Pérez Vejo y Marco A. Landavazo, coords., Imágenes e imaginarios sobre España en México, siglos XIX y XX (Morelia: Porrúa / Universidad Michoacana de San Nicolás de Hidalgo, Instituto de Investigaciones Históricas / Conacyt, 2006).

${ }^{23}$ Telésforo García, "La palabra del abuelo", Rojo y Gualda, año I, núm. 31 (18 de noviembre de 1916); "Magistral pieza oratoria leída por don Telesforo García", ibid., año Il, núm. 47 (10 de marzo de 1917), publicado en varias entregas.

${ }^{24}$ Las fechas de inicio están comprobadas en todos los casos. No así las de finalización, pues de algunas no tenemos la certeza de que sea el último número, sino tan solo el
} 
estrecha como la colonia española, la mayor parte de estas publicaciones tuvo una vida efímera (algunas apenas alcanzaron la veintena de números) y otras intentarían fusionarse para continuar existiendo. ${ }^{25}$

A todo ello se debe añadir que el tiempo en que Ricardo de Alcázar desarrolló su formación periodística, obtuvo sus primeros trabajos en la profesión y llevó a cabo sus primeras iniciativas editoriales, además de coincidir con los sucesos revolucionarios coincidió también con importantes cambios en la prensa, no sólo en México, sino en general en el mundo occidental, cuando el periodismo se orientó hacia las masas, abarató su precio y se multiplicaron las tiradas. ${ }^{26}$

Durante la Revolución desaparecieron viejos periódicos y periodistas y aparecieron otros totalmente nuevos, como El Universal o Excélsior, con una rápida y amplia difusión nacional. Según Javier Garciadiego, desde 1916, con el triunfo de Carranza, los cambios en la prensa nacional y capitalina fueron de tal magnitud que se puede considerar el momento decisivo "en el proceso de modernización del periodismo mexicano". Para Ana María Serna, esta nueva prensa adquirió a partir de 1920 su función esencial de intermediaria entre la opinión pública y el Estado. ${ }^{27}$

Ante este contexto, la prensa española de información diaria no era capaz de competir y terminó por hacerse inviable. Los periodistas inmigrantes, sin embargo, supieron adaptarse y lograron mantenerse en la profesión gracias a su inmersión en la prensa de tirada nacional mexicana de esa época. Formaron parte de ese mundo en crecimiento colaborando en los medios mexicanos e intentando, al mismo tiempo, mantener a flote los españoles. ${ }^{28}$

último ejemplar conservado en los repositorios consultados, por ejemplo Tricolor. Una Revista Mexicana de Cultura.

${ }^{25}$ Como ejemplo, en el último número de Castillos y Leones se anunciaba su unión con la revista Don Quijote, con "el ideal que nos hemos trazado hace años relativo a que exista un gran semanario español entre nosotros". Editorial, "Don Quijote y Castillos y Leones", Castillos y Leones, año III, núm. 29 (23 de enero de 1922).

${ }^{26}$ Ana María Serna, "Prensa y sociedad en las décadas revolucionarias (1910-1940)", Secuencia. Revista de Historia y Ciencias Sociales, núm. 86 (2014): 109-149.

27 Javier Garciadiego, "La prensa durante la Revolución mexicana", en Las publicaciones periódicas y la historia de México, ed. de Aurora Cano Andaluz (México: UNAM, 1995), 82; Ana María Serna, "Periodismo, Estado y opinión pública en los inicios de los años veinte (1919-1924)", Secuencia. Revista de Historia y Ciencias Sociales, núm. 68 (2007): 59, acceso el 30 de abril de 2021, https://doi.org/10.18234/secuencia.v0i68.1005.

${ }^{28}$ Miquel, "Presentación" a Españoles en el periodismo mexicano, 193-194. Los textos de muchos de ellos circularon regularmente en publicaciones mexicanas, por ejemplo los diarios Excélsior, El Universal y semanarios como Revista de Revistas y El Universal llustra- 
Así, envuelto en este contexto histórico y periodístico, Ricardo de Alcázar llegó, como decíamos, en 1913 a Ciudad de México y comenzó a trabajar de corrector de estilo y crítico de teatro en el diario El Imparcial, uno de los más importantes de la ciudad, durante la última etapa del rotativo, con Salvador Díaz Mirón al frente, con quien había hecho amistad en Veracruz; también entregaba sus críticas teatrales a El Demócrata. ${ }^{29}$ Al mismo tiempo, su firma aparecía asociada también a El Diario Español, en el que colaboró, junto al cántabro José Albuerne, por unos meses antes de su absorción por El Correo Español, de manera que el escritor alternó su trabajo en los medios mexicanos y españoles. ${ }^{30}$

En 1915 Florisel aparece como editor en la que probablemente fuera la primera iniciativa del periodo para editar un semanario cultural propio de los españoles, El Otro Mundo, junto al también crítico teatral valenciano Francisco Martínez de Bujanda. La revista recibió la bendición de los viejos intelectuales de la colonia española. El influyente Telésforo García apuntaba esto sobre El Otro Mundo:

era discreto, atinado y decía en formas elegantes de nuestro incomparable idioma [...] de la España científica, artística, pintoresca, inventora, industrial, parlamentaria y hasta torera [...]. Y después de esto, que ya es mucho, un cuidado exquisito de pasar discretamente sobre las molestas dificultades íntimas de la colonia, [...] y una infatigable tenacidad en poner de resalto [sic] cuanto honra y eleva a España en el exterior... ${ }^{31}$

do, al igual que en españoles como El Imparcial, $A B C$ (y su semanario Blanco y Negro), El Sol, El Siglo Futuro, El Heraldo de Madrid y otros.

${ }^{29}$ Bada, Ricardo de Alcázar, 25-27. En El Imparcial Ricardo de Alcázar, junto a José Albuerne, defendía una sección teatral intitulada "Apuntes Rápidos". Véanse El Imparcial, 11 de febrero de 1914: 3 y El Demócrata. Paladín Revolucionario, 3 de noviembre de 1914. En sus entregas firmaban como Florisel y Perdicaris.

${ }^{30}$ Maria y Campos, Reseña histórica, 90-91. El Diario Español se publicó durante dos años y medio y, según este autor, fue el primero de la prensa española que tuvo servicio cablegráfico de Madrid y provincias; El Correo Español, "su rival de toda la vida", terminó absorbiéndolo, ya en la época de Lorenzo Serrano. El director de El Diario Español, Pablo Rodríguez, atribuyó la desaparición del diario a la "falta de apoyo por parte de los más, unida a la situación general del país."

${ }^{31}$ Telésforo García, "A Ricardo de Alcázar y compañeros de labor española", Rojo y Gualda, añol, núm. 1 (25 de marzo de 1916). 
Sin embargo, la falta de rentabilidad económica y las desavenencias de ambos editores con la empresa que publicaba la revista, una librería regentada por el español Andrés Botas y su hijo, obligaron a De Alcázar y a Martínez de Bujanda-cinco meses y 19 números después-a renunciar al proyecto. ${ }^{32}$

Tan sólo unos meses después de cerrar El Otro Mundo, en marzo de 1916 salió a la venta el primer número de Rojo y Gualda, con Ricardo de Alcázar como único editor y un claro objetivo continuista. En su Bosquejo biográfico del escritor, el médico y amigo Juan José Bada explicaba: "Con el dinero que le dio un amigo nuestro, excelente persona, Dn. Ceferino del Campo, fundó una revista semanal que tituló 'Rojo y Gualda' y que editaba en la imprenta de Dn. Manuel León Sánchez". ${ }^{33}$

En una carta publicada en la sección de apertura del segundo número, Martínez de Bujanda, su antiguo socio, animaba así al editor: "Ojalá que, muerto El Otro Mundo, en tu Rojo y Gualda sepas hacer, solo, lo que no pudimos hacer en El Otro Mundo los tres unidos: labor española, labor hispanoamericana, y demostrar que si tenemos algo malo en nuestra colonia -al fin es numerosatenemos mucho bueno...". 34

Este nuevo intento sí arraigó y de Rojo y Gualda se editaron 223 números, hasta su cierre en septiembre de 1920. Nuevamente, conocidas personalidades de la comunidad migratoria, como el citado Telésforo García o Tomás G. Perrín, médico y escritor castellano de amplia reputación en México, mostraron abiertamente su beneplácito a la publicación: "Y vaya aquí otro aplauso para Rojo y Gualda, que en aras de un patriótico romanticismo es portavoz de la cultura hispana". ${ }^{35}$ Para Armando de Maria y Campos, periodista y autor de la Reseña histórica del periodismo español en México, el semanario "merece en todo instante un cálido recuerdo, porque durante largos años fue el órgano espiritual de

32 "Otra carta y punto final", Rojo y Gualda, núm. 3 (8 de abril de 1916), carta de Andrés Botas a De Alcázar.

${ }^{33}$ Bada, Ricardo de Alcázar, 28. La semblanza de Florisel publicada en un artículo breve por el Casino Español hace algunos años agrega que fueron Telésforo García y el empresario Elías Pando Pendás, con quienes hizo amistad, los que le ayudaron a fundar la revista. "Florisel. Un treviense ilustre", 21-22.

${ }^{34}$ Francisco Martínez de Bujanda, "Una carta", Rojo y Gualda, año I, núm. 2 (10. de abril de 1916).

35 Tomás G. Perrín, "Programa espiritual de la Unión Española", Rojo y Gualda, núm. 37 (30 de diciembre de 1916). La alusión a la revista aparece en una conferencia de Perrín en el Casino Español de la Ciudad de México que Rojo y Gualda reproduce. Véase también Tomás G. Perrín, "Nuestro Espaldarazo", ibid., núm. 1 (25 de marzo de 1916). 
los españoles de México y el más justo reflejo de cuanto de bueno y de noble ocurría en la Península". ${ }^{6}$

De Alcázar dirigió la revista durante 16 meses, hasta el número 66, publicado el 21 de julio de 1917. Sobre su labor al frente del semanario, Juan José Bada reconocía: "Todo lo hacía éste: de director, redactor y corrector de pruebas; con más [sic] un agente de anuncios, que se veía negro para conseguir uno; y unas tijeras. Para cada número escribía un artículo de índole literaria o de interés para la colonia española, y una crónica teatral". ${ }^{37}$ A lo largo de ese tiempo lo acompañó como administrador José Albuerne, a quien vendió la revista cuando se marchó. En el Editorial del número 70, el nuevo director introducía la siguiente nota informativa:

Por convenio escrito, celebrado, con fecha 12 del corriente, entre el señor D. Ricardo de Alcázar y el que suscribe, "Rojo y Gualda" pasa a la exclusiva pertenencia del Sr. Albuerne, el cual desde ahora se encarga de dicha publicación con el carácter de director-propietario, quedando el señor Alcázar desligado por completo de esta empresa, por convenir a sus intereses. ${ }^{38}$

La revista no ofreció explicación alguna respecto a la salida de su fundador, lo único que sabemos es que, al parecer, poco después De Alcázar abandonó la capital y se trasladó a vivir a Mérida, invitado por el escritor yucateco Antonio Mediz Bolio, donde trabajó como redactor de La Voz de la Revolución durante varios meses. ${ }^{39}$ Rojo y Gualda continuó su andadura tres años más bajo la dirección de otros periodistas españoles, como veremos después.

A su regreso a Ciudad de México, Florisel intentó una vez más echar a andar una nueva empresa periodística, en un denodado intento por dotar a la colonia de un órgano diario de prensa informativa, el vespertino El Día Español, junto al escritor y periodista catalán Enrique Guardiola Cardellach como secretario de redacción. ${ }^{40}$ Los esfuerzos que puso en el empeño aparecen retratados en el citado Bosquejo biográfico de Bada, en el cual narra cómo varios empre-

\footnotetext{
${ }^{36}$ Maria y Campos, Reseña histórica, 100.

${ }^{37}$ Bada, Ricardo de Alcázar, 29.

38 José Albuerne, "Editorial", Rojo y Gualda, año II, núm. 70 (8 de agosto de 1917).

39 Payo Franco, "Se van Villaespesa y Mediz Bolio", El Nacional, ca. 1917 (no se distingue la fecha exacta).

${ }^{40}$ Maria y Campos, Reseña histórica, 97-101. Guardiola Cardellach había sido redactor en El Correo Español desde la etapa de Porrúa, y con Lorenzo B. Serrano ocupó el cargo de jefe de redacción.
} 
sarios de la comunidad española habían financiado las instalaciones y gastos iniciales de El Día Español:

La defensa que Florisel había hecho en su revista de todos los valores españoles, así del espíritu como materiales, no pasó inadvertida para unos cuantos compatriotas suyos destacados en los negocios [...] convinieron en la necesidad de fundar un periódico diario. [...] Se juntaron allí además de Elías [Pando], Santiago Galas, Antonio Muñiz, un tal De la Fuente y Laureano Migoya. Por lo pronto, cada uno contribuiría con mil pesos, y ya verían de allegar fondos de otros amigos. ${ }^{41}$

Florisel y Guardiola, junto a dos periodistas más, se encargaban de redactar las diferentes secciones (Internacional, Deportes, Cables, etc.) de las ocho páginas que tuvo inicialmente el rotativo, y que el editor corregía diariamente. ${ }^{42}$ Además de sus habituales crónicas teatrales, Florisel escribía los artículos literarios y defendía "los valores espirituales de España, los morales y materiales de sus compatriotas". En los años siguientes, y a través del diario, Florisel inició una campaña de propaganda con el propósito de unir los diversos centros sociales españoles de la capital, bajo el título "Unión y fusión". No lo consiguió, dada la tendencia disgregadora de los suyos, pero ayudó a que finalmente se crease el Colegio de la Unión Española. ${ }^{43}$ Asimismo, en esta época el escritor viajó a España durante varios meses y en Madrid estableció contacto con intelectuales como Alfonso Reyes, quien era encargado de negocios de México en España. ${ }^{44}$

El Día Español creció lentamente y en 1924 logró convertirse en diario matutino, pero dos años más tarde el escritor decidió vendérselo al cónsul de origen mallorquín Carlos Badía Malagrida quien, con un permiso del servicio exterior español y acudiendo nuevamente al apoyo financiero de los poderosos de la colonia, "le dio un gran impulso al periódico". ${ }^{45}$ De hecho, es el único

\footnotetext{
${ }^{41}$ Bada, Ricardo de Alcázar, 32.

${ }^{42}$ Maria y Campos, Reseña histórica, 103. Poco después pasaría a tener la mitad de planas. De acuerdo con este autor "Guardiola escribía de pie sobre la repisa de la taquilla de la imprenta, y Florisel también de pie, apoyando la cuartilla en la pared".

${ }^{43}$ Bada, Ricardo de Alcázar, 33.

44 "Florisel. Un treviense ilustre", 22.

45 Ibid., 34. Maria y Campos, Reseña histórica, 109. El Día Español sobrevivió hasta 1932, cuando una huelga obligó a la empresa que lo publicaba a liquidarlo. La semblanza del escritor en el Boletín del Casino afirma que éste fue su director y gerente tan solo hasta 1923.
} 
diario de la colonia española del cual tenemos noticia que sobreviviera a lo largo del decenio de los años veinte.

Tan solo unos meses después de su salida de El Día Español, el periodista emprendió su último y más ambicioso proyecto como editor, la revista literaria La Voz Nueva. Revista Semanal de Información, Opinión y Comentarios. En su primera página aparecía toda una declaración de intenciones, donde Florisel expresaba la esencia de los cambios que sustentaban su nuevo proyecto: “¿Pero hace falta decirlo aún? La Voz Nueva, fundamentalmente hispanicista [sic], tiende a demostrar que, no solo no hay incompatibilidad alguna entre México y España, sino que, en la raíz, en el fondo y a la larga todo es una y la misma cosa". ${ }^{46}$

De esta revista salieron a la luz un total de 46 números, al principio con formato de semanario, pero un año después, en 1928, comenzó a editarse mensualmente y aunque en los años siguientes faltó a su cita editorial en alguna ocasión, mantuvo dicha periodicidad hasta enero de 1931. Bebió de las principales corrientes literarias y filosóficas de la época y acercó a Florisel a los círculos intelectuales mexicanos de finales de la década de 1920, sobre todo a los autores más destacados de la generación de los Contemporáneos (Novo, Villaurrutia, Owen), quienes colaboraron en ella a través de la publicación de sus poemas o de ensayos breves. ${ }^{47}$

La Voz Nueva no fue el único proyecto editorial en el que participó De Alcázar en esta década. En enero de 1930 apareció una nueva cabecera con titularidad española -pero factura claramente mexicana-: El Espectador. Teatros, Cine, Arte y Literatura, que 14 números después cambió su subtítulo a Revista de Arte y Literatura. Salió a la venta solamente hasta julio del mismo año, con periodicidad semanal y el poeta español Humberto Rivas Panedas, hijo del también escritor Juan Pablo Rivas, como director. ${ }^{48}$

Al frente de la redacción de El Espectador estaban los poetas mexicanos Xavier Villaurrutia, Celestino Gorostiza, Ermilo Abreu Gómez, Bernardo Ortiz de

\footnotetext{
${ }^{46}$ Ricardo de Alcázar, La Voz Nueva, núm. 1 (11 de noviembre de 1927).

${ }^{47}$ Alicia Gil Lázaro, "La Voz Nueva. El sueño editorial de Ricardo de Alcázar (1927-1932)", en Las migraciones europeas a América Latina. Nuevas perspectivas socioculturales a través del estudio de la prensa, ed. de Juan Andrés Bresciano (Montevideo: Universidad de la República, Centro de Estudios Interdisciplinarios, Facultad de Humanidades y Ciencias de la Educación, 2021), 9-43.

${ }^{48}$ Pilar García-Sedas, Humberto Rivas Panedas. El gallo viene en aeroplano. Poemas y cartas mexicanas (Madrid: Renacimiento, 2009), 93-94. Según esta autora, aunque El Espectador fue una revista revolucionaria en el panorama teatral mexicano, el reconocimiento de Humberto Rivas en las artes escénicas del país fue casi nulo en su tiempo.
} 
Montellano, Manuel Rodríguez Lozano y Julio Castellano, así como el propio De Alcázar. Por primera vez la nómina de colaboradores de una revista se nutrió de firmas mexicanas, en mayor medida que españolas. El Espectador reservaba un espacio para la poesía bajo el epígrafe Antología, nuevamente con piezas del director, Rivas Panedas y poetas de la generación de los Contemporáneos como Villaurrutia, Gorostiza y Gilberto Owen, junto a poemas de los españoles Juan Ramón Jiménez y Federico García Lorca, entre otros. Puede considerarse que, con La Voz Nueva y El Espectador, se verificó un cambio fuerte en la producción periodística española, que ya venía desde una década atrás en revistas como Tricolor de Julio Sesto, pero que ahora se confirmó: el de su acercamiento y conexión plena con las letras y las bellas artes mexicanas, entrando en una nueva época, en la cual el periodismo español terminaría mexicanizándose.

El escritor no emprendió nuevos proyectos editoriales después de los años 30, pero sus obras siguieron publicándose durante esa década y la siguiente. La mayor parte de su producción escrita a lo largo de ese tiempo estuvo dedicada a la crítica literaria, ${ }^{49}$ aunque también publicó varios poemarios ${ }^{50}$ y fue traductor de obras literarias y ensayos en varios idiomas. ${ }^{51}$ Desde 1932, su vida transcurriría estrechamente unida a una institución emblemática de la comunidad, el elitista Casino Español, donde fungió como director de la comisión de cultura hasta su fallecimiento. ${ }^{52}$

${ }^{49}$ En algunos de sus ensayos demostró su devoción castiza por la lengua castellana peninsular: en Por el alma y el habla de Castilla (1922) o Cómo hablamos en México (Sintaxis sin tasa oral y escrita cogida al vuelo) (1944). La defensa de la historia colonial española en América, frente a la creciente influencia cultural estadounidense, fue otro tópico de su obra: El cuento y la cuenta del oro de América (1927) y, por supuesto, la defensa de la imagen y el papel de la colonia española en México, en El cetro, las cruces y el caduceo (en busca de la conciencia de la colonia (1928), o El gachupín, problema máximo de México (1934), al tiempo que criticaba la fragmentación de sus instituciones y de la colonia misma en Unión, fusión y confusión de la colonia (un esquema de superestructura racional) (1928).

${ }^{50}$ Donaire (1931), Ofrenda al silencio (arrepentimiento de Donaire) (1931), La voz del silencio y la otra (1937), Epistolario de amor y de amistad (1939), Cuatro poemas (1942). Juan José Bada cita estas obras, de las que no se ha podido localizar la fecha ni la referencia: Nuevo Donaire, La cara del día, Sancta Simplícitas, los ojos del Paisaje y En las palmas de la noche. Bada, Ricardo de Alcázar, 112.

51 Traducciones del francés: Literatura, de Paul Valéry (1933); Introducción a la poética, de Paul Valéry (1938); El misántropo, de Molière. En inglés: Las avanzadas de la Ciencia, de Jorge W. Gray (1940).

52 Bada, Ricardo de Alcázar, 38. 
En 1940 Xavier Villaurrutia escribió esto sobre Florisel, a propósito de su traducción de una obra poética de Paul Valéry: "Solo un poeta está capacitado para realizar una tarea cuyos resortes secretos se ocultan a quien no lo sea. Ricardo de Alcázar lo es y de calidad. Un conocimiento seguro de nuestro idioma y un placer de filólogo por las etimologías lo colocan en una situación ventajosa con relación a traductores menos bien armados".53

Esta breve semblanza biográfica de Florisel deja traslucir el influjo que ejerció la revista Rojo y Gualda en la revitalización de la actividad periodística, cultural, literaria e intelectual de la colectividad española radicada en la capital mexicana en el tiempo de la Revolución, de modo que a continuación nos referiremos a ella, primero a través de una visión general de la publicación en sus cinco años de existencia y después centrando la atención en su primera etapa, a cargo de este escritor.

\section{Rojo y Gualda. Una revista española en México}

\section{Las etapas y sus directores}

A lo largo de los cuatro años y medio en los que se publicó Rojo y Gualda, la dirección pasó por las manos de cuatro periodistas inmigrantes: a Ricardo de Alcázar y José Albuerne sucedieron el poeta asturiano Alfonso Camín y el periodista madrileño Felipe Velasco (alias Don Nadie). Albuerne dirigió el semanario durante un año y medio, con una línea editorial continuista respecto a su antecesor. Rojo y Gualda creció en tamaño y aumentó el espacio para la publicidad, lo que permitió a Albuerne incluir a dos periodistas en plantilla.

En la tercera entrega de enero de 1919, el cántabro se despidió como director y anunció quién le sustituía, aunque, al contrario de Florisel, esta vez sí expresaba la causa de su separación de la revista: "Circunstancias particulares en las que pesan, no poco, las fatigas cargantes de esta tarea que nunca se acaba, oblíganme a ceder el puesto al compatriota Alfonso Camín, del que huelga toda presentación por ser bien conocido entre los nuestros y también entre todo el elemento intelectual de la República". ${ }^{54}$

${ }^{53}$ Xavier Villaurrutia, "Traduciendo a Paul Valéry", en Textos y pretextos (México: UNAM 1940). En 1941, Villaurrutia le dedicó a su amigo Ricardo de Alcázar el poema "Décima muerte".

54 José Albuerne, "Mi despedida", Rojo y Gualda, año IV, núm. 144 (18 de enero de 1919). Durante la guerra, el editor se había manifestado abiertamente progermanista y antinorteamericano, utilizando la revista como palestra de sus críticas, lo que tal vez influyera 
Así pues, tras 144 números publicados, la dirección de Rojo y Gualda pasó al poeta asturiano, quien había llegado a México unos meses atrás, procedente de Cuba, iniciando una pronta colaboración con otras publicaciones mexicanas. En el mismo Editorial donde Albuerne se despedía, apareció el siguiente texto de Camín:

YO DIJE AYER: Que los españoles en Méjico necesitan un periódico genuinamente español, claro espejo de las palpitaciones en allende y aquende el mar. Que, fuera de la Patria, debemos hacer exposición de las cosas magnas y no escarnio de nuestras flaquezas. Si existe la llaga, poner el cauterio donde otros ponen el ultraje. Que en nuestra colonia debemos discutir los problemas, no los hombres. Y que ese periódico debe ser para los españoles algo único; no una hoja suelta más, sostenedora del amor propio de éste o aquél grupo de amigos, como ahora sucede, de tal manera, que más que españoles en tierra extranjera parecemos políticos de barriada en surco propio. ${ }^{55}$

El poeta se encargó de los 70 números siguientes, en los que, nuevamente, la marcada personalidad del editor y sus gustos estéticos imprimieron un sello distintivo a la publicación. Camín personalizó la revista, de manera que su presencia en ella fue mayor que la de los directores anteriores, a través de los editoriales, artículos de opinión y poemas. Aunque no perdió de vista el mundo intelectual español y las colaboraciones provenientes de la península, Rojo y Gualda se acercó más al modelo periodístico de la colonia que había predominado hasta entonces en la prensa étnica española en México. La revista redobló su intervención en los asuntos internos del belicoso grupo español, respondiendo a cuanta diatriba y desencuentro se producía en su seno, y protagonizando incluso alguno de ellos. ${ }^{56}$

Tras año y medio al frente de Rojo y Gualda, acusando un prolongado desgaste en la dirección del semanario, el poeta -como había hecho Albuerne- utilizaría el Editorial del número 210 para justificar su despedida: "Fatigas

finalmente en su separación, Rojo y Gualda, año III, núm. 108 (11 de mayo de 1918). Este mismo número apareció con la siguiente expresión, bajo el título de la primera página: "Semanario español. Boycoteado [sic] por la cancillería yanqui".

${ }^{55}$ Alfonso Camín, "Yo dije ayer", Rojo y Gualda, año IV, núm. 144 (18 de enero de 1919).

${ }^{56}$ Son varios los estudios que han hecho hincapié en las desavenencias constantes de la colonia española y los conflictos en sus organismos asociativos. Véase Gil Lázaro, Inmigración y retorno, 138-147; también Gutiérrez Domínguez, "Tensiones y conflictos...". 
materiales, mayores luchas morales para mantener en pie mi integridad de periodista, de español y de hombre, desvelos, muchos desvelos y otras mil peripecias, serían incontables los obstáculos que he tenido que allanar para salir adelante, sin recursos económicos, sin recurso de anuncio...". ${ }^{57}$

En mayo de 1920 la dirección quedaba en manos de Felipe Velasco, que había sido su administrador durante un tiempo. El madrileño no consiguió editar más que 11 números antes del cierre definitivo. ${ }^{58}$ En septiembre de 1920, Rojo y Gualda contaba con 14 colaboradores en plantilla, entre ellos un dibujante y un caricaturista, un humorista, un cronista de toros, otro de deportes y un "agente exclusivo de anuncios". ${ }^{59}$

\section{El formato, los costos y las estrategias editoras}

A pesar de estos vaivenes, desde un punto de vista formal Rojo y Gualda fue consecuente con el formato ofrecido al público, siguiendo un modelo muy extendido entre las revistas culturales y literarias ilustradas del último tercio del siglo XIX y las primeras décadas del XX: periodicidad semanal, tamaño entre las 20 y 30 páginas, financiación sostenida con las suscripciones y la publicidad inserta en sus páginas, portadas con ilustraciones a color, algunas secciones fijas escritas casi siempre por los mismos colaboradores y una nómina más o menos amplia de contribuciones, algunas de ellas frecuentes y otras esporádicas.

En primer lugar, al contrario que otras revistas de la colonia española del periodo, Rojo y Gualda apareció puntual cada sábado desde el inicio hasta el fin, si bien su tamaño sufrió ligeras variaciones en el tiempo, probablemente relacionadas con los aprietos económicos que los propios directores reconocían cada tanto y que tal vez les obligaban a disminuir los contenidos.

En los primeros números el precio de la revista fue de 1 peso, pero un par de meses después, a partir del número 20, se elevó a 2 pesos: "¡iTotal nada! Al lector, que seguramente nos hará el inmerecido honor de suponer que también nosotros nos debatimos heroicamente, como pez sin agua, dentro de las mallas de esa fatal red de la vida de relación comercial que todos por igual sufrimos,

\footnotetext{
${ }^{57}$ Alfonso Camín "Mi despedida", Rojo y Gualda, año V, núm. 210 (1o. de mayo de 1920).

${ }^{58}$ Ana María Serna, "Prensa y sociedad...", 109-149. De acuerdo con esta autora, Felipe Velasco había participado de joven, en su Madrid natal, en organizaciones de extrema izquierda. En México colaboró habitualmente en El Heraldo, La Raza y El Diario, y durante el periodo del presidente Calles sus intervenciones en la prensa nacional en apoyo del mismo y contra la Iglesia católica fueron numerosas.

${ }^{59}$ Alfonso Camín, "Los de casa", Rojo y Gualda, año V, núm. 223 (10. de septiembre de 1920).
} 
no le extrañará esta ligera alza en el precio de Rojo y Gualda". ${ }^{60}$ En octubre de ese mismo año el costo subió a 3 pesos. ${ }^{61}$ En marzo de 1917 comenzaron a aparecer los precios de suscripción a la revista, diferenciando los de la capital y los de los Estados, al tiempo que se anunciaba que un agente del semanario iría a Puebla, con objeto de hacer nuevas suscripciones y establecer "una activa corresponsalía".62

Juan José Bada menciona los problemas financieros de la revista en estos términos: "La revista 'Rojo y Gualda', limpiamente impresa y de muy selecto contenido, era 'pura literatura' para los comerciantes. No tenía anuncios, y como el encargado de conseguirlos no iba provisto de un garrote, con mirada canina o furibunda y con la amenaza de un vituperio, el comerciante español se abstenía". ${ }^{63}$

El punto de venta de Rojo y Gualda en la capital estaba en la Librería Española, en la Avenida 5 de Mayo, donde también se realizaban las suscripciones y se contrataban los anuncios. La revista incluía la publicidad de la librería, y la presentaba como "Agencia de Rojo y Gualda". Sus anuncios eran de tamaño reducido, con mensajes como "Librería Española: recibe, vende y reparte a domicilio periódicos y revistas de España, con las últimas noticias de la guerra europea", o "No olvide usted que recibimos periódicos ilustrados de España a los mejores precios de plaza". ${ }^{64}$

Como ya se dijo, un porcentaje importante de las contribuciones incluidas en cada número se debía a autores peninsulares y contenidos relacionados con España ¿Cómo se hacía Florisel con ellos? La procedencia de estos textos no se solía especificar en la revista, pero la actualidad de los debates intelectuales y políticos peninsulares que Rojo y Gualda reflejaba número tras número permite

60 "Dos pesos por Rojo y Gualda", Rojo y Gualda, año I, núm. 10 (3 de junio de 1916).

${ }^{61}$ A finales de 1916 se produjo una estabilización monetaria en México, tras los graves procesos inflacionarios vividos a lo largo de la Revolución. Esto hizo que el precio de la revista se situara, a partir de noviembre de ese año, en 20 céntimos y así permaneciera hasta junio del año siguiente, cuando subió a 25 céntimos, precio con el cual se vendió hasta su cierre, exceptuando los números especiales, como los de Covadonga o el onomástico del rey, ocasiones en que se elevó a 40 o 50 centavos.

62 "Propaganda de Rojo y Gualda para Puebla", Rojo y Gualda, año II, núm. 50 (31 de marzo de 1917). Las suscripciones podían hacerse anuales, semestrales y trimestrales, y ofrecían notables rebajas cuanto más tiempo se contrataban.

${ }^{63}$ Bada, Ricardo de Alcázar, 31.

${ }^{64}$ Rojo y Gualda, año I, núm. 28 (28 de octubre de 1916); ibid., año Il, núm. 68 (4 de agosto de 1917). 
inferir que la Librería surtía al editor con una fuente amplia de publicaciones españolas de primera mano, gracias a las cuales éste se ponía al día, buscaba sus contactos y eventualmente conseguía las colaboraciones.

Por otro lado, la relación comercial e intelectual entre los periodistas y escritores de ambos lados del océano era una realidad muy frecuente en esta época en la que buena parte de los profesionales de la escritura vendían sus textos a distintas publicaciones como modo de vida, y para ello era crucial estar bien conectado con el mundo editorial de habla hispana. ${ }^{65} \mathrm{~A}$ las redes personales y los contactos sociales por medio de los cuales se verificaban los envíos y los pagos, se añadía la existencia de agencias "literarias" -no sólo informativas- que ejercían como empresas intermediarias entre los escritores y las publicaciones, localmente o a una mayor escala. Estas agencias eran también habituales en la época, por lo que el papel de la Librería pudo haber sido importante en este sentido.

Con cierta frecuencia Florisel aclaraba al inicio de un artículo su procedencia, que solía ser otra revista o periódico en donde previamente se había publicado: "El gran diario La Prensa de Buenos Aires, publica el siguiente admirable artículo que honra tanto a España como a quién lo escribió...." ${ }^{66} \mathrm{~A}$ menudo se refería a la buena relación que le unía con el editor de dicha publicación, o con el autor: "Nuestro querido amigo DON QUIETO -O sea, Pacífico Redondo en el mundo de las fórmulas civiles- esa incansable voz nuestra que tiene en El Nacional el honroso cargo diario de hablar de España ha escrito este bello artículo que reproducimos con todo gusto". ${ }^{67}$

Con todo, no puede descartarse que Florisel, tijeras en mano (la metáfora con la que lo recordaba su amigo Bada), ${ }^{68}$ publicara algunos textos editados previamente sin recabar los debidos permisos ni pagar los derechos de autor. La nómina amplísima de autores que, como se verá más tarde, desfilaron por

\footnotetext{
65 Julio Sesto, "Larga crónica de un largo viaje", Tricolor, núm. 11 (abril de 1918). Sesto relata, en esta crónica de su viaje a España, los encuentros que sostuvo en Madrid con diferentes artistas y escritores, para solicitarles colaboraciones para su revista. Citado en Juan Pascual Gay, "Alfonso Camín y su Antología de poetas sevillanos (1929)", Revista del Colegio de San Luis III, núm. 6 (julio-diciembre de 2013): 19.

66 "España y las naciones de su origen", Rojo y Gualda, año I, núm. 33 (2 de diciembre de 1916).

${ }^{67}$ Pacífico Redondo, "Mensajero de amor", Rojo y Gualda, año II, núm. 48 (17 de marzo de 1917).

${ }^{68}$ Véase nota 37.
} 
la revista, unida a los escasos recursos con que contaba habitualmente, hacen plausible esta hipótesis. ${ }^{69}$

\section{La estética y la publicidad}

La estética con la que nació Rojo y Gualda, incluso en sus portadas a color, fue bastante sobria y de factura modesta. Ninguno de los números tenía paginación y sólo hasta bien avanzada la edición empezó a aumentar la presencia de fotografías, caricaturas, dibujos u ornamentos gráficos en su interior, que entroncaban estéticamente con el Modernismo. En el tiempo de Florisel como editor, las portadas de la revista mantuvieron siempre un mismo objetivo: "poner cara" a personajes ilustres de las letras, las artes o las ciencias españolas. De este modo se sucedieron, una tras otra, reproducciones cuasi-fotográficas que mostraban únicamente el rostro de los "Prestigios españoles", título que se les adjudicaba en la misma página.

Literatos como Pío Baroja, Cervantes, Azorín, la condesa de Pardo Bazán, Juan Ramón Jiménez o Ramón del Valle-Inclán; pintores como Julio Romero de Torres, Santiago Rusiñol o Ignacio Zuloaga; hombres de ciencia como Leonardo Torres Quevedo o José Echegaray desfilaron en las portadas junto a otros tantos célebres cantantes, actores y actrices, músicos, escultores, periodistas, médicos, catedráticos de universidad y políticos de actualidad. Sólo en los números especiales, como el que se publicó con motivo de la celebración de la festividad de la Virgen de Covadonga o el del Día de la Raza, este modelo se rompía, optando por figuras alegóricas o símbolos patrios, que enfatizaban el móvil identitario de la revista.

Pronto la publicidad se incrustó también en las portadas, sin que se perdiera la idea original de esa estética, ya que ocupaba una esquina de la página o rodeaba incluso el rostro del personaje con un marco donde se anunciaba una casa comercial. ${ }^{70}$ La portada conectaba a menudo la expresión gráfica inicial con una parte de los contenidos, normalmente un artículo referido al mismo perso-

\footnotetext{
69 John H. Sinningen, "La presencia de la obra de Benito Pérez Galdós en la prensa mexicana", en Españoles en el periodismo mexicano, 186. Sobre cómo La Iberia publicó la novela Trafalgar de Galdós bajo la forma de folletín, este autor comenta: "todo esto sin pagar derechos de autor [...] los editores mexicanos publicaban lo que les viniera a mano [...] un hurto como cualquier otro". Cabe pensar que esta práctica se hallara extendida en el mundo periodístico de entonces, a ambos lados del Atlántico.

${ }^{70}$ Rojo y Gualda, año I, núm. 20 (2 de septiembre de 1916). Portada dedicada a Enrique Gómez Carrillo.
} 
naje o escrito por él; o incluso un número monográfico, como fue el caso del número 5, dedicado enteramente a Cervantes con motivo del tercer centenario de su muerte. ${ }^{71}$

La publicidad se ubicaba sobre todo al principio y al final del semanario; solía ocupar alrededor de un tercio de la publicación, entre seis y ocho páginas completas. Las páginas interiores introducían anuncios en la parte inferior y en los huecos entre las columnas. Tras la portada solía incluirse en primer lugar la cartelera de teatros capitalinos, con los estrenos de la semana. ${ }^{72}$ Buena parte del espacio publicitario se llenaba con anuncios de las casas comerciales españolas (sombrererías, textiles, zapaterías, dulcerías, joyeros o abarrotes, entre otras), pero también se desplegaban a página entera carteles de diversas compañías industriales como la Tabacalera Mexicana, las empresas petroleras, bancarias o de transporte, junto a otras de menor tamaño (imprentas, restaurantes, talleres mecánicos, consultas médicas particulares u otros servicios).

\section{La estructura de la revista, las secciones y géneros más habituales}

La estructura respondía, como no podía ser de otra forma, a los dos objetivos principales que sostenían la revista: actuar como mirador de la cultura hispánica en México, por un lado, y captar la atención de sus potenciales lectores, la colonia de residentes en la capital, aludiendo a temas que fueran de su interés y entraran en la órbita castiza de "lo español", por otro. Las páginas de Rojo y Gualda incluían, por tanto, artículos dedicados a las regiones españolas, el idioma castellano, los hitos y grandes gestas de su historia, las letras, artes, la cultura o actualidad política nacional e internacional, que alternaban con contenidos orientados al ámbito local de la colonia capitalina, los consabidos temas de la vida asociativa y el entretenimiento. Bajo la dirección de Florisel la primera parte predominó claramente sobre la segunda.

\footnotetext{
71 Ibid., núm. 5 (22 de abril de 1916). El contenido de este número abrió con el Editorial titulado "Nuestro Miguel", al que siguió una serie de artículos sobre el escritor y su obra: "Vida de Cervantes", "La casa de Cervantes", "Opinión de algunos grandes franceses sobre la obra maestra", o "Instrumentos y canciones del Quijote", entre otros.

72 Sin duda Florisel tenía fuertes conexiones con el mundo del teatro, los dueños de los establecimientos, otros críticos como él, actores y actrices. Así, en los primeros números se publicitaba la empresa de su antiguo socio Francisco Martínez de Bujanda, en el Teatro Colón, o del Teatro Mexicano. Se representaban obras de dramaturgos españoles contemporáneos como Jacinto Benavente, Manuel Linares Rivas, Pedro Muñoz Seca, Francisco Villaespesa o Gregorio Martínez Sierra, autores que encontraban también cabida en los contenidos de la revista.
} 
El semanario mantuvo a lo largo de sus cinco años de vida una serie de secciones fijas, casi siempre relacionadas con el segundo y más local de los objetivos, mientras que el espacio destinado al primero se distribuía de forma aleatoria a lo largo de sus páginas, sin un orden aparente ni regularidad en su aparición. Los títulos de las secciones y el lugar que ocupaban fueron cambiando a lo largo del tiempo. Algunas se consolidaron y aumentaron de tamaño, en tanto que otras siguieron el camino contrario, su espacio fue disminuyendo y terminaron por desaparecer.

La sección más estable desde el inicio fue la deportiva, dedicada por completo al fútbol y denominada "Con Pie Forzado", título que mantuvo el primer año, para cambiar después simplemente a "Sección Deportiva". En ella se hizo muy popular Mario Fernández, un comentarista aficionado que además publicitaba su negocio de sastrería en las páginas de Rojo y Gualda y cuyas reseñas concitaron un interés creciente de los lectores, seguidores de los equipos españoles de la colonia y de las ligas mexicanas en las que participaban, que le escribían a menudo, en respuesta a sus artículos. ${ }^{73}$ Con el tiempo entraron otros comentaristas deportivos, así como más deportes, aunque el "balompié" mantuvo su predominio. Fue la primera sección en introducir caricaturas, de los jugadores y los árbitros, sobre todo.

A partir de número 4 se abrió una sección nueva titulada "La Semana Española", con formato de noticias breves, en una o dos páginas, relativas a la actualidad política, social, económica y cultural de la península. Florisel aprovechaba a veces esta sección para insertar bloques compactos de información, por ejemplo discursos del monarca español o del jefe de gobierno en turno, así como decretos de ley y reales órdenes aprobadas en esos años y que podían entroncar con las preocupaciones de los lectores, como la Real Orden publicada el 26 de agosto de 1916, relativa al indulto a prófugos, desertores y no alistados, o la Real Orden que detallaba la documentación que debían llevar los españoles que regresaran a la patria. ${ }^{74}$

${ }^{73}$ Antonio Otero, "Musa pedestre. La balompedestrería", Rojo y Gualda, año I, núm. 31 (18
de noviembre de 1916); artículo dedicado a Mario Fernández: Ruperto Liedo, "Al Sr. Don
Mario Fernández. Cronista y campeón de Balómpie", ibid., año II, núm. 38 (6 de enero de
1917). Otros comentaristas posteriores fueron Don Facundo, Quimera, Joselín y B. Junco.
Eventualmente aparecían noticias de carreras de automóviles, como la Hispano-Suiza.
${ }_{74}^{74}$ Rojo y Gualda, año I, núm. 19 (26 de agosto de 1916) y núm. 55 (5 de mayo de 1917).
Otro ejemplo es "La semana española. Discurso de S. M. en elogio de dos grandes espa-
ñoles. En la Academia de Ciencias Exactas" (29 de abril de 1916), se trata de un homenaje
a José Echegaray y Leonardo Torres Quevedo. A partir de octubre de 1916 la sección 
Táctica habitual de esta sección era copiar noticias de otros medios de prensa, insertando la referencia correspondiente. "La Semana Española" no apareció en todos los números, incluso podía pasar meses enteros sin salir. A finales del primer año de vida, la revista estrenó una sección paralela titulada "España en Méjico", que se mantuvo también de forma estable, aunque intermitente y con carácter misceláneo: igual transcribía las opiniones vertidas en la prensa europea por Manuel Sánchez Azcona sobre la situación mexicana, que relataba la visita al Casino Español de intelectuales de prestigio como Antonio Caso y Amado Nervo o periodistas como Félix Palavicini, entre otros. Detrás de esta sección se hallaba a menudo la pluma de Florisel. ${ }^{75}$

En estos dos primeros años las alusiones al teatro y a los toros no adquirieron una sección propia en sentido estricto. Las crónicas de los eventos celebrados en ese tiempo en México o España podían tener un reflejo puntual en la revista, e incluso encabezarse eventualmente con un título como "Gracia, coraje y majeza" en el caso de la información taurina, o "Los cómicos y las obras" para el teatro. En el primer caso, eran comentaristas taurinos muy conocidos en la península los que firmaban las crónicas (como Ángel Caamaño, El Barquero, o Joaquín López Barbadillo). ${ }^{76}$ En el segundo caso era Florisel quien se encargaba. ${ }^{77}$

Sin duda, estas noticias actuaban como gancho de atracción para un público muy concreto, y, por tanto, no se podía prescindir de ellas, pero ocuparon un espacio marginal en los contenidos de esta etapa de la revista y en los temas predilectos del editor. Más repercusión parecía tener la inclusión de pequeños fragmentos de obras dramáticas o cómicas, así como de páginas poéticas, que atraían también mucho a los lectores y formaron secciones ocasionales, constituyéndose un género muy popular en la revista. ${ }^{78}$ Así, por ejemplo, a lo largo

cambió de nombre a "Últimas Noticias de España" y también apareció como "Noticias de España".

${ }^{75}$ Ricardo de Alcázar, "España en Méjico. El doctor Perrín", Rojo y Gualda (23 de diciembre de 1916). Sobre el texto de Sánchez Azcona véase nota 9. De igual forma, numerosas contribuciones llevaban por título "España en América", "España en Estados Unidos", "España en Argentina", "España en Berlín", etc. A menudo los textos estaban asociados a un escritor y tenían continuidad en varios números, consecutivos o intermitentes.

${ }^{76}$ Ángel Caamaño, El Barquero, "De Madris a Barselona y visideversa", Rojo y Gualda, año I, núm. 6 (29 de abril de 1916); "En Madrid, última del primer abono", ibid., núm. 11 (24 de junio de 1916); "Gracia, Coraje y majeza", ibid., núm. 19 (26 de agosto de 1916).

77 Florisel, "La virtud es todo lo contrario", ibid., núm. 22 (16 de septiembre de 1916).

${ }^{78}$ Los títulos de las secciones poéticas fueron cambiando. La primera denominación fue "Lira española", le siguió "Versos prosaicos", con la firma de Carlos Miranda, "Páginas festivas", "Musa galante" y otros. 
de los primeros años se publicaron reiteradamente "sainetes rápidos" del comediógrafo español Carlos Arniches, bajo el rótulo eventual de "El buen humor en España".79

A partir del número 20, Florisel aceptaba un tanto irónicamente incluir un folletín al final de cada entrega, con lo que se consolidó una sección más en el género de ficción:

Toda publicación periódica que aspire a vida larga tiene que recurrir, quieras que no, a la inveterada costumbre del folletín, porque entre los lectores de todo periódico hay siempre un gran número de ellos que no puede concebir un diario o un semanario sin el fragmentario y sucesivo relato de algo extraordinariamente novelesco que dé al periódico así como un cierto y seguro sentido de cosa a la vez continua y permanente, que establezca entre el número que pasó y el que va a venir ese enlace de unidad que informa siempre la vida o la razón de vida de todo ser. ${ }^{80}$

Pero los textos por entregas no se ciñeron únicamente a las piezas literarias, sino que el semanario siguió este mismo modelo con otros géneros, como el ensayo de carácter histórico. Así, a partir del número 49, en marzo de 1917, comenzó a publicarse el libro de un escritor y periodista estadounidense, Carlos Fletcher Lummis, titulado Los exploradores españoles del siglo XVI (en inglés, The Spanish Pioneers), sobre la Conquista de América, en defensa del mestizaje de la cultura española y contra el racismo anglosajón de la época. ${ }^{81}$

La mayor parte de las colaboraciones no se pueden categorizar en ninguna sección. Algunos textos y sus autores tienen cierta continuidad, como las "Crónicas Científicas", de José Echegaray, donde el autor comentaba los cambios científicos de la época; "Las Flores de la Guerra", reportajes sobre la I Gue-

\footnotetext{
${ }_{79}$ Carlos Arniches, "La pareja científica”, Rojo y Gualda, año I, núm. 2 (10. de abril de 1916); "A la vejez", ibid., núm. 3 (8 de abril de 1916); "El zapatero filósofo", ibid., núm. 5 (22 de abril de 1916); "La risa del pueblo", ibid., núm. 9 (20 de mayo de 1916); "Los ambiciosos", ibid., año II, núm. 42 (3 de febrero de 1917), entre otros.

80 "Hindenburg ante Belmonte", ibid., año I, núm. 20 (2 de septiembre de 1916). Presentación del folletín de Fernando Luque, a cargo de Florisel. Los otros dos folletines incluidos en la etapa de este editor fueron "Se vende un alma", de Emilio Ferraz Revenga, y "Un hombre que llegó a ser Dios", de H. Wells.

${ }^{81}$ Carlos Fletcher Lummis, "Los exploradores españoles del siglo XVI", Rojo y Gualda, año II, núm. 49 (24 de marzo de 1917). Las entregas tuvieron continuidad después de la separación de Florisel de la revista, hasta el núm. 106 (27 de abril de 1918).
} 
rra Mundial, de Eugenio Noel; o "La Historia Dorada" de Eduardo Marquina, que comentaba hechos y personajes históricos conocidos. ${ }^{82}$ Un género que también se mantuvo estable de principio a fin fue la entrevista, de la mano de un conocido periodista especializado en la "interviú", José María Carretero Novillo, alias El Caballero Audaz, muy famoso en España por su estilo peculiar y sus exhaustivas entrevistas a personajes famosos de la política, las artes y las letras. ${ }^{83}$ Pero lo habitual en cada número era el predominio de artículos sin sección.

Una última sección fija de la revista estuvo dedicada a lo largo de la etapa de Ricardo de Alcázar a la Unión Española de Méjico (UEM), iniciativa colectiva de las élites económicas de la colonia con el fin de allegar fondos para paliar los daños que la Revolución había provocado en las vidas de sus compatriotas, suministrando socorros, pasajes de repatriación, trabajo, etc.

Número tras número, el editor mostró el compromiso adquirido con la UEM de hacer de Rojo y Gualda el órgano de expresión de la institución, de tal manera que en sus páginas se fueron publicando sus estatutos, reglamentos, haberes y la gestión económica llevada a cabo por una segunda instancia erigida a partir de la UEM, la Junta Española de Auxilios, que canalizó las ayudas en el peor momento de la crisis de subsistencias que asoló a la capital mexicana entre 1915 y 1916: "Rojo y Gualda, en su modesta esfera de acción, escribirá y obrará, siempre ecuánime, con la virtuosa satisfacción del que quiere y sabe cumplir con su deber, en armonía perfecta con esa noble, patriótica y cultural idea que, de hoy en más, y esperamos que, por siempre, se denominará la Unión Española de Méjico. Amén". ${ }^{84}$

${ }^{82}$ Eduardo Marquina, "La rendición de Breda", Rojo y Gualda, año I, núm. 4 (15 de abril de 1916); "La historia dorada: Doña Juana infanta", ibid., núm. 8 (13 de mayo de 1916); "La historia dorada: el testamento de Isabel", ibid., núm. 9 (20 de mayo de 1916); "Juana la loca", ibid., núm. 13 (8 de julio de 1916). José Echegaray, "Crónica Científica", ibid., núm. 9 (20 de mayo de 1916); núm. 16 (29 de julio de 1916); núm. 21 (9 de septiembre de 1916); núm. 22 (16 de septiembre de 1916). Los textos de Echegaray aparecieron en Rojo y Gualda hasta unas semanas después de su muerte. "Una pluma clara", reproduce una colaboración del escritor para El Diario de la Marina, de La Habana, de septiembre de ese año, ibid., núm. 28 (28 de octubre de 1916). Eugenio Noel, "Las Flores de la Guerra", ibid., núm. 14 (15 de julio de 1916); núm. 17 (12 de octubre de 1916); núm. 29 (4 de noviembre de 1916).

${ }^{83}$ El Caballero Audaz, "Armando Palacio Valdés", ibid., núm. 3 (8 de abril de 1916); "Azorín", ibid., núm. 6 (29 de abril de 1916); "Pompeyo Gener", ibid., núm. 9 (20 de mayo de 1916); "Carlos Arniches", ibid., núm. 12 (10. de julio de 1916).

${ }^{84}$ Ricardo de Alcázar, "La Unión Española de Méjico", ibid., núm. 6 (29 de abril de 1916); "La Unión Española", ibid., núm. 24 (30 de septiembre de 1916). 
Fruto de esta colaboración, la revista comenzó a incluir gradualmente anuncios encargados por la UEM, como una bolsa de empleo, las campañas de vacunación, los llamamientos a maestros y profesores españoles para cubrir las vacantes del Colegio, y otros: "A los ESPAÑOLES: La Unión Española de Méjico ha abierto entre sus asociados, un registro de establecimientos de comercio, negociaciones industriales y oficinas en general, que pueden necesitar empleados de ambos sexos y de todas las edades; y otro destinado a anotar los nombres y cualidades de los compatriotas que se encuentran sin trabajo". 85

\section{Los colaboradores y los temas de la revista}

Los colaboradores, o más en puridad, los autores que firmaban los textos con los que se nutría la revista conformaban un amplísimo y heterogéneo cuadro de hombres y mujeres, españoles y de otras nacionalidades, residentes en la península, en México o en otros puntos de la geografía americana, y, sobre todo, de figuras de reconocido prestigio la mayoría de ellos. Pertenecían a generaciones literarias distintas, a corrientes literarias y de pensamiento variadas, y la mayor parte alternaban, como solía suceder, su quehacer creador con otras tareas de carácter más práctico, como el periodismo, la ciencia, la enseñanza o las bellas artes.

Sus textos circulaban por la prensa de la época, en los periódicos o revistas más afamadas, y a menudo aparecían publicados a la vez en varias de ellas en geografías distantes. Prácticamente todas las tendencias estéticas de finales del siglo XIX y las primeras décadas del XX estaban representadas en estas aportaciones: Modernismo, decadentismo, naturalismo o simbolismo, así como las generaciones literarias noventayochista y novecentista.

La selección de autores que Florisel hacía para su semanario revela, sin duda, su exhaustivo conocimiento del panorama de la cultura española y europea de ese periodo, así como su nivel elevado de lectura y actualización literaria. Mediara o no una relación mercantil entre la revista y los autores de los textos, su inclusión permite advertir el bagaje intelectual del editor, sus preferencias literarias, sus búsquedas y preocupaciones intelectuales esenciales. Sin embargo, tan abigarrada lista de firmas no permite en modo alguno encuadrar a Rojo y

\footnotetext{
85 Ibid., año II, núm. 49 (24 de marzo de 1917). A partir de esta fecha, anuncios similares se insertaron semanalmente. También hizo lo propio la Legación de España en México, que entregó puntualmente al director una lista de personas desaparecidas, de quienes se buscaba su paradero. Ibid., núm. 56 (12 de mayo de 1917).
} 
Gualda o a su autor en una corriente o ideología concreta. Al contrario, delata más bien cierto empeño de su director por convocar y dar a conocer al mayor número posible de autores, ideas, tendencias y personalidades, afán pedagógico al que parecía unirse un ansia constante por elevar la calidad literaria de su revista.

En primer lugar, aunque la mayor parte de las aportaciones aparecían firmadas por hombres, las escritoras estaban representadas por intelectuales de la talla de Emilia Pardo Bazán, aristócrata novelista y periodista; Margarita Nelken, crítica de arte que adquirió relevancia política durante la Segunda República; y Carmen de Burgos Seguí (Colombine), conocida periodista, escritora y activista en defensa de los derechos de la mujer. Otras firmas no menos relevantes que también aparecieron en Rojo y Gualda fueron las de la crítica literaria Blanca de los Ríos; la ensayista cubana afincada en España Salomé Núñez Topete; la poeta y novelista Sofía Casanova, primera corresponsal de un país extranjero en guerra; la académica y pedagoga Magdalena Santiago Fuentes; la artista y directora de cine mexicana Mimí Derba, y otras. ${ }^{86}$ Todas escribían a la vez que ejercían el periodismo y eran respetadas entre los círculos intelectuales españoles y americanos de las primeras décadas de siglo.

Por otro lado, dadas las dificultades con las que se topó Florisel para hacerse con un registro amplio de suscriptores que sostuviera su revista, tuvo que ir cediendo terreno a temas más cercanos y de interés para los españoles que la compraban. Para ello dio cabida en las páginas de Rojo y Gualda a un número reducido de compatriotas expatriados como él y dedicados a la escritura, con los que compartía su inserción singular y en minoría dentro de la colonia española -no eran productores en sentido estricto, como el grueso del grupo-, así como a las principales preocupaciones que los acompañaban.

Algunos se dedicaban profesionalmente al periodismo, como Andrés Peláez Cueto, José Albuerne o Alberto Barella, mientras que otros ejercían ocupaciones diversas y la escritura suponía una actividad complementaria. Las con-

${ }^{86}$ Condesa de Pardo Bazán, "Eduardo Pondal", Rojo y Gualda, año I, núm. 54 (28 de abril de 1917); Margarita Nelken, "Un gran retratista español", ibid., núm. 30 (11 de noviembre de 1916); Carmen de Burgos, "La gracia española. La tortajada", ibid., núm. 35 (16 de diciembre de 1916); Blanca de los Ríos, "Impresiones literarias de 1916", ibid., año Il, núm. 47 (10 de marzo de 1917); Salomé Núñez y Topete, "Tonos y tono", ibid., año I, núm. 7 (7 de mayo de 1916); Sofía Casanova, "Desde Rusia", ibid., año II, núm. 57 (19 de mayo de 1917); Magdalena S. Fuentes, "Cátedras al aire libre. Irradiaciones de cultura", ibid., año I, núm. 16 (29 de julio de 1916); Mimí Derba, "De la vida vulgar", ibid., núm. 24 (30 de septiembre de 1916). 
ferencias del médico Juan José Bada, o las crónicas deportivas del sastre Mario Fernández son ejemplo de los segundos. Florisel era generoso en alabanzas: "Nuestro culto compatriota el ingeniero y escritor Baltasar Fernández Cué ha publicado un interesante y sereno artículo [...] con cuya reproducción honramos estas páginas". Sobre Barella decía: "Joven español muy leído que el jueves 22 dio una conferencia muy documentada y amena acerca del teatro catalán". ${ }^{87} \mathrm{~A}$ través de ellos Rojo y Gualda no perdió en ningún momento, por tanto, su carácter de revista para la colonia española. Sus ensayos breves la conectaban con el mundo que le rodeaba, con temas recurrentes como los problemas de la emigración, el papel de los españoles en las circunstancias que se vivían en 1916 y la marcha de las instituciones grupales, entre otros. Acudían autores de otros géneros fuera del ensayo, como el cuento corto o la poesía. ${ }^{88}$

Por la revista desfilaron grandes figuras de las letras mexicanas como Alfonso Reyes, Luis G. Urbina, Antonio Caso, Amado Nervo o Francisco A. de Icaza. ${ }^{89}$ Es probable que el tiempo de Florisel en El Imparcial, la cercanía a Salvador Díaz Mirón y sus frecuentes colaboraciones en otras publicaciones fueran factores de acercamiento al modernismo literario del país. ${ }^{90}$ Esta generación de

${ }^{87}$ Baltasar Fernández Cué, "Otro poco sobre la hispanofilia", Rojo y Gualda, año II, núm. 49 (24 de marzo de 1917), de El Demócrata, 19 de marzo de 1917; Rojo y Gualda, año II, núm. 50 (31 de marzo de 1917). Juan José Bada, "Una noticia a la colonia española. El desamparo de nuestras mujeres", ibid., núm. 66 (21 de julio de 1917); Alberto Barella, "Las hipótesis de la Victoria", ibid., núm. 61 (16 de junio de 1917); José Albuerne, "Plenitud de vacío", ibid., núm. 56 (12 de mayo de 1917); Andrés Peláez Cueto, "El comercio español en Méjico", ibid., núm. 53 (21 de abril de 1917); "La arquitectura del siglo", ibid., núm. 54 (28 de abril de 1917); "La carestía de las subsistencias", ibid., año I, núm. 6 (29 de abril de 1916). ${ }^{88}$ José Albuerne (que firmó en Rojo y Gualda con el pseudónimo de Pepín de Cantabria), "Así por el estilo. Perfil castellano (cómo escribe Azorín)", Rojo y Gualda, año I, núm. 20 (2 de septiembre de 1916); "Ecos de la Covadonga", ibid., núm. 22 (16 de septiembre de 1916). Al final de cada número, la revista incluía un Índice Social Español, con las asociaciones españolas y sus domicilios sociales. También se incluyeron varios textos de los corresponsales en Puebla, Veracruz y Pachuca, aunque esta línea se exploraría más en las siguientes etapas de la revista.

${ }^{89}$ Fósforo, "El cine, diálogo crítico", Rojo y Gualda, año I, núm. 15 (22 de julio de 1916); el pseudónimo de Fósforo aparece asociado tanto a Reyes como a Luis Martín Guzmán. Alfonso Reyes, "Libros nuevos", ibid., año II, núm. 66 (21 de julio de 1917); Antonio Caso, ibid., núm. 48 (17 de marzo de 1917); Francisco A. de Icaza, "La risa, el hambre y la muerte", ibid., año I, núm. 22 (9 de septiembre de 1916); Luis G. Urbina, "El problema del libro español", ibid., núm. 37 (30 de diciembre de 1916).

90 Ricardo de Alcázar, "El milagro del poeta", Rojo y Gualda, año Il, núm. 48 (17 de marzo de 1917). Dedicado a Palavicini, Antonio Caso, Cravioto y otros. 
autores compartía su cercanía con España y algunos habían pasado largas temporadas fuera de México durante la Revolución. Pero la presencia de escritores mexicanos fue minoritaria en la revista, frente a los autores españoles.

Los poetas, novelistas y ensayistas latinoamericanos tampoco faltaron, pero no dejaron de ser también una minoría. Entre ellos se encuentran Pedro E. Ureña, José E. Rodó, Manuel Ugarte, Enrique Gómez Carrillo o Rubén Darío. ${ }^{91}$ Sus ensayos miraban hacia la literatura, el cine, las bellas artes, la estética y la lírica. Asimismo, se publicaron artículos de periodistas españoles establecidos en otras latitudes americanas, como Felipe Aparicio (El bachiller Alcañices), desde Chile, o Carlos Malagarriga, muy conocido en la prensa española de Argentina. ${ }^{92}$

Rojo y Gualda se concibió, como hemos reiterado, mirando hacia España y lo español y por ello la nómina más importante de aportaciones se nutrió de autores peninsulares. Incluía, en primer lugar, a los pesos pesados de la generación del 98, escritores, ensayistas y poetas como Miguel de Unamuno, Azorín, Pío Baroja, Ramiro de Maeztu, Ángel Ganivet, Jacinto Benavente, Francisco Villaespesa, los hermanos Antonio y Manuel Machado, Enrique de Mesa, Ramón del Vallé-Inclán y el filólogo Ramón Menéndez Pidal. ${ }^{93}$ La revista publicó colabo-

${ }^{91}$ Pedro E. Ureña, "España en los Estados Unidos", Rojo y Gualda, año I, núm. 3 (8 de abril de 1916); Pedro E. Ureña, "Enrique Granados. Goyescas", ibid., núm. 4 (15 de abril de 1916); José Enrique Rodó, "La España niña", ibid., año Il, núm. 64 (7 de julio de 1917); Manuel Ugarte, "El ilustre poeta", ibid., núm. 60 (9 de junio de 1917); Rubén Darío, ibid., año I, núm. 6 (29 de abril de 1916); "Un soneto", ibid., núm. 9 (20 de mayo de 1916). Enrique Gómez Carrillo, "El problema del libro español", ibid., núm. 34 (9 de diciembre de 1916). El problema de la industria del libro español fue un tema al que se le dio una cobertura amplia en la revista.

92 El bachiller Alcañices, "España en Chile", Rojo y Gualda, año II, núm. 38 (6 de enero de 1917); Carlos Malagarriga, "España en la Argentina", ibid., núm. 41 (27 de enero de 1917), firmado en Buenos Aires (8 de noviembre de 1916).

${ }^{93}$ Ángel Ganivet, "Del idearium español. Los dos sistemas coloniales", Rojo y Gualda, año II, núm. 39, (13 de enero de 1917). Pío Baroja, "el maestro Escabarte o la limitación", ibid., año I, núm. 2 (1o. de abril de 1916); "El milagro de la campana", ibid., núm. 20 (2 de septiembre de 1916); Ramón del Valle Inclán, "Cuento de abril", ibid., núm. 23 (23 de septiembre de 1916); "Una escena de la Marquesa Rosalinda", ibid., núm. 30 (11 de noviembre de 1916); Azorín, "La fiesta", ibid., núm. 25 (7 de octubre de 1916); "El amor al pasado", ibid., año II, núm. 45 (24 de febrero de 1917); Miguel de Unamuno, "El cetro estéril", ibid., año I, núm. 26 (14 de octubre de 1916); "Con don Quijote en Sigüenza", ibid., núm. 27 (21 de octubre de 1916); Ramón Menéndez Pidal, "Dos sonetos inéditos de Fray Luis de León”, ibid., año II, núm. 49 (24 de marzo de 1917); Enrique de Mesa, "Cancionero castellano", ibid., núm. 50 (31 de marzo de 1917); Manuel Machado, "El día de 'Juan José"', ibid., núm. 61 (16 de junio de 1917); Francisco Villaespesa, "Conferencia", ibid., núm. 64 (14 de julio de 1917). 
raciones frecuentes de algunos de ellos, como en el caso de Unamuno; de otros, tan solo de forma esporádica. Incluso Florisel no dejó de mirar aún más atrás en el tiempo, con aportaciones de autores realistas como Armando Palacio Valdés o románticos tardíos como Salvador Rueda. ${ }^{94}$

Los textos publicados ahondaban en los temas caros a este grupo, la crítica ante la postración moral, política y social de España, la errada modernización del país, lastrada por el atraso y las guerras coloniales, y la preocupación por la identidad de lo español, especialmente por las tierras de Castilla y de sus pueblos abandonados, y el habla castiza y campesina. ${ }^{95}$ Otros autores igualmente importantes, por ejemplo Rafael Altamira o Joaquín Costa, el máximo representante del llamado regeneracionismo, plantearon el problema de la personalidad histórica de España, que encontró un eco importante en las páginas de Rojo y Gualda. ${ }^{96}$ Entre los periodistas cercanos a la generación del 98, Florisel incluyó en la revista a figuras de prestigio como Mariano de Cavia, Manuel Bueno, José María Salaverría, José Ortega Munilla y Manuel Ciges Aparicio, entre otros. ${ }^{97}$

Con esta panoplia de autores Florisel pudo participar de las principales tramas argumentales de las que se habían revestido las corrientes del hispanoamericanismo. ${ }^{98}$ Así, se le dio un lugar importante en la revista a las relaciones

${ }^{94}$ Armando Palacio Valdés, "El krishna de las trincheras", Rojo y Gualda, año I, núm. 15 (22 de julio de 1916); Salvador Rueda, "La bandera española", ibid., año II, núm. 40 (20 de enero de 1917).

95 Juan José Llovet, "Piedras segovianas", Rojo y Gualda, año I, núm. 23 (23 de septiembre de 1916); Melchor de Almagro San Martín, "Por tierras de España. Viaje fervoroso", ibid., núm. 29 (4 de noviembre de 1916); "Por tierras de España. El sentido realista de Castilla", ibid, núm. 30 (11 de noviembre de 1916), artículo que trata sobre Ávila; "Zamora o la caballerosidad", ibid., núm. 31 (18 de noviembre de 1916).

${ }^{96}$ Rafael Altamira, "España en los Estados Unidos. La Sociedad Hispánica de América", Rojo y Gualda, año I, núm. 2 (10. de abril de 1916); "Las 'posibilidades de España", ibid., núm. 9 (20 de mayo de 1916); Joaquín Costa, "La leyenda es más verdad que la historia", ibid., año Il, núm. 55 (5 de mayo de 1917).

97 Manuel Bueno, "Campo de Armiño. Jacinto Benavente", Rojo y Gualda, año I, núm. 3 (8 de abril de 1916); "Los nuevos blasones", ibid., núm. 12 (10. de julio de 1916); José Ortega Munilla, "Desde España: la muerte de Granados y los barcos españoles hundidos", ibid., núm. 10 (3 de junio de 1916); "Un homenaje a Alarcón”, ibid., núm. 16 (29 de julio de 1916); Mariano de Cavia, "El pleito de la tía fingida”, ibid., núm. 12 (1o. de julio de 1916); "Coloquios de Omar y Alí", ibid., núm. 30 (11 de noviembre de 1916); José María Salaverría, "Los negadores de España", ibid., año II, núm. 39 (13 de enero de 1917).

${ }^{98}$ Editorial, "España y las naciones de su origen", Rojo y Gualda, año I, núm. 33 (2 de diciembre de 1916); Luis Araquistáin, "Hispanoamericanismo", ibid., núm. 1 (25 de marzo de 1916); José María Salaverría, “España en América”, ibid., núm. 31 (18 de noviembre de 1916). 
entre España y las naciones americanas, al igual que al nuevo papel que debía asumir la antigua metrópoli en el concierto internacional, especialmente en su relación con Europa y también en lo que concernía a la expansión estadounidense y los peligros que comportaba para el resto del continente. ${ }^{99}$ Otro de los focos de atención de Rojo y Gualda fue la revalorización de un glorioso pasado español, apelando una y otra vez a los hitos clásicos de la formación del Estado, como el reinado de los Reyes Católicos, o a la biografía de personajes como el Cid, el Gran Capitán o Cristóbal Colón. ${ }^{100}$

En una línea similar se situaba el elogio a la historia compartida entre España y América -la gesta conquistadora, la colonización, la cristianización-, así como la herencia transmitida al continente a través de la lengua castellana, la raza hispánica o la religión católica. ${ }^{101}$ Finalmente, otro de los argumentos recurrentes del repertorio narrativo hispanoamericano fue la presencia fuerte en aquellos años de la expansión de la nación española por medio de sus emigrantes, depositarios de los más altos valores de la raza y protagonistas de una nueva gesta civilizatoria, a través de su esforzado trabajo, su sacrificio y, en general, su aporte económico y cultural en los países de destino. ${ }^{102}$

Las revistas en las que los escritores noventayochistas publicaron sus textos en España -Don Quijote, Germinal y Vida Nueva, entre otras- constituyeron una fuente de inspiración para Florisel. Especialmente lo fue Germinal (18971904), ${ }^{103}$ que aglutinó un conjunto de autores que se autodenominaron Gente Nueva, nombre que Florisel, recordemos, tomó para bautizar su primera revista en Veracruz. Escritores y periodistas de este grupo como Joaquín Dicenta,

99 Salvador de Madariaga, "La América española", Rojo y Gualda, año I, núm. 21 (9 de septiembre de 1916); "La independencia de Filipinas", ibid., núm. 27 (21 de octubre de 1916); Mariano González-Laris, "La influencia de la civilización española en América Latina", ibid., núm. 21 (9 de septiembre de 1916).

${ }_{100}$ Marcelino Menéndez y Pelayo, "España, cuna del derecho internacional", Rojo y Gualda, añol, núm. 4 (15 de abril de 1916); La semana española, "Conmemoración patriótica del Gran Capitán", ibid.; Francisco J. de Gamoneda, "España en la historia ¿quiénes fueron los héroes", ibid., año II, núm. 40 (20 de enero de 1917).

101 Luis de Zulueta, "La expansión del castellano", Rojo y Gualda, año I, núm. 17 (12 de agosto de 1916); Mariano de Cavia, "La fiesta de la raza", ibid., núm. 32 (25 de noviembre de 1916); Cristóbal de Castro, "La fiesta de la raza”, ibid., núm. 31 (18 de noviembre de 1916). 102 Baltasar Fernández Cué, "La colonia española y el medio ambiente", Rojo y Gualda, año II, núm. 54 (28 de abril de 1917); Rafael Altamira, "El legado de Pedro Vila y las escuelas para emigrantes", ibid., año I, núm. 28 (28 de octubre de 1916).

${ }^{103}$ Rafael Pérez de la Dehesa, El grupo "Germinal": una clave del 98 (Madrid: Taurus, 1970). 
Eduardo Zamacois, Rafael Delorme o Antonio Zozaya fueron habituales de Rojo y Gualda. ${ }^{104}$

La Gente Nueva partía de una identidad enclavada en la política, propugnaba actualizar los idearios republicanos y acercarlos al socialismo, estrechar los vínculos con el "pueblo" y ser eco de los "trabajadores honrados". Entre ellos se encontraban también algunos autores con ideología anarquista. Su cabida en el semanario de De Alcázar es una muestra más de la heterogeneidad ideológica bajo la que se movió el editor. Incluso sus efigies fueron apareciendo una tras otra en las portadas de la revista. Otros periodistas de ideología republicana que desfilaron por sus páginas (algunos terminarían exiliándose en México dos décadas después) fueron Mario Aguilar Baena, Prudencio Iglesias Hermida y Luis de Zulueta. ${ }^{105}$ Sin embargo, Florisel no dejó de mostrarse también subyugado por el poder de oratoria de políticos como Juan Vázquez Mella, en las antípodas del republicanismo, del que publicó varias de sus largas conferencias. ${ }^{106}$

La generación del 14, o novecentistas (ya que muchos de ellos nacieron a finales del siglo), se halla también representada en las páginas de la revista de Florisel. El intelectual con mayor prestigio entre ellos fue, como sabemos, el filósofo José Ortega y Gasset y, junto a los de él, Rojo y Gualda reprodujo textos de novelistas y ensayistas de altura como Ramón Pérez de Ayala, Salvador de Madariaga o Wenceslao Fernández Flores, dramaturgos como Gregorio Martínez Sierra y Manuel Linares Rivas, poetas como Juan Ramón Jiménez o Ramón Gómez de la Serna. ${ }^{107}$ No se trató solamente de una generación literaria, sino

104 Joaquín Dicenta, "La Goya”, Rojo y Gualda, año I, núm. 22 (16 de septiembre de 1916); Antonio Zozaya, "La arcilla del genio", ibid., núm. 33 (2 de diciembre de 1916); "Los nuevos pasos honrosos", ibid., año II, núm. 64 (7 de julio de 1917); Eduardo Zamacois, "A América por España", ibid., núm. 39 (13 de enero de 1917).

105 Prudencio Iglesias Hermida, "La belleza, las armas y las letras", Rojo y Gualda, año I, núm. 3 (8 de abril de 1916); "El atraco", ibid., núm. 23 (23 de septiembre de 1916); Mario Aguilar, "Un próximo triunfo español. Blasco Ibáñez, cinematografista", ibid., núm. 20 (2 de septiembre de 1916); "Barcelona flamenca", ibid., núm. 26 (14 de octubre de 1916); Manuel Linares Rivas, "Toninadas. Los aplausos teatrales", ibid., núm. 27 (21 de octubre de 1916); Luis de Zulueta, "Soliloquios de un español. Nuestra mayor riqueza", ibid., núm. 37 (30 de diciembre de 1916).

106 Juan Vázquez Mella, "La unión de las derechas", Rojo y Gualda, año I, núm. 10 (3 de junio de 1916); "Fiesta de la poesía gallega en La Coruña", ibid., núm. 28 (28 de octubre de 1916); "Maravilloso discurso de Vázquez de Mella", ibid., no. 29 (4 de noviembre de 1916). 107 José Ortega y Gasset, "Tierra de Castilla", Rojo y Gualda, año I, núm. 17 (12 de agosto de 1916); "Balance vital", ibid., núm. 20 (2 de septiembre de 1916); Salvador de Madariaga, 
también científica, con la influencia fuerte en la revista de José Echegaray, Leonardo Torres Quevedo y otros. ${ }^{108}$

Se trataba de una generación que aunó a los vástagos de una burguesía bien asentada con pretensiones modernizadoras, que tuvieron una actitud activa en la política, quienes se acercaron también a las vanguardias artísticas de la época desde una perspectiva elitista, con una alta valoración de la formación intelectual. Se arrogaron la responsabilidad colectiva de dar respuesta a las preguntas acuciantes de aquel momento sobre qué era España y lo que debía ser. Su conciencia intelectual se manifestaba en la crítica abierta a la sociedad dominante y en la búsqueda de una nueva, más moderna y floreciente: su propósito era la transformación social de España, a través de la cultura y la ciencia. Se le Ilama generación de 1914, pues la I Guerra Mundial fue un hecho significativo para sus componentes. Las aportaciones de estos autores acerca de la guerra ocuparon un espacio destacado en las primeras etapas de Rojo y Gualda, con reflexiones sobre el conflicto, la tecnología, la neutralidad española, las consecuencias económicas para España y para América Latina, la germanofilia o aliadofilia, y otras. ${ }^{109}$

Por último, una amplia nómina de periodistas situados en la corriente del regionalismo o provincialismo fueron también preferentes en los temas del editor. El sevillano José Mas, al que Rafael Cansinos Assens llamaba "cantor de la provincia"; Alfredo Nan de Allariz, escritor gallego muy vinculado a la literatura de la emigración, y el también gallego Alejandro Pérez Lugin; el madrileño Pedro de Répide, nombrado "cronista de la villa"; Constantino Cabal, representante del asturianismo literario, fueron algunos de ellos. Se movieron entre el

"El caballero del desequilibrio", ibid., núm. 13 (8 de julio de 1916); Ramón Pérez de Ayala, "El allegro", ibid., núm. 15 (22 de julio de 1916); "Lira castellana", ibid., núm. 31 (18 de noviembre de 1916); Ramón Gómez de la Serna, "El doctor inverosímil", ibid., núm. 23 (23 de septiembre de 1916); Gregorio Martínez Sierra, "Las guitarras mágicas", ibid., núm. 25 (7 de octubre de 1916); Wenceslao Fernández Flores, "Procesión de millones", ibid., año Il, núm. 46 (3 de marzo de 1917).

108 José Echegaray, "El ovillo de bramante y la locomotora", Rojo y Gualda, año I, núm. 24 (30 de septiembre de 1916); "El kilográmetro", ibid., núm. 25 (7 de octubre de 1916); Leonardo Torres Quevedo, "Maravillas del ingenio español", ibid., año II, núm. 45 (24 de febrero de 1917). Véase también la nota 79.

109 Miguel de Zárraga, "Los que se enriquecen a costa de la guerra", Rojo y Gualda, año I, núm. 36 (23 de diciembre de 1916). Destacan las crónicas germanófilas de Antonio Azpeitua, "España en Berlín. La prudencia de España", ibid., año II, núm. 45 (24 de febrero de 1917); Manuel Linares Rivas, "La guerra", ibid., núm. 62 (23 de junio de 1917). 
Romanticismo y el realismo costumbrista, el naturalismo finisecular, y la novela social y política de principios del nuevo siglo. ${ }^{110} \mathrm{Su}$ especialidad fueron las escenas costumbristas de las regiones, especialmente de Asturias, Santander, País Vasco y Galicia, las regiones donde la sangría migratoria hacia México y al resto de América fue más fuerte. ${ }^{111}$

En contraposición, Florisel invitó asiduamente a colaborar en la revista a algunos autores cosmopolitas como Julio Camba, bien conocido por sus crónicas viajeras impregnadas de humor, especialmente durante su etapa en Estados Unidos, y Luis Bonafoux, especializado en los reportajes sobre Europa y la crónica de la I Guerra Mundial, entre otros. ${ }^{112}$

\section{Conclusiones}

La edición de una revista cultural española en su país de acogida fue una aspiración que acompañó buena parte de la trayectoria profesional e intelectual del periodista, editor y escritor Ricardo de Alcázar, Florisel. El proyecto se materializó en varias ocasiones entre las décadas de 1910 y 1930, con intentos de duración y formato variable, pero con objetivos y contenidos similares: promover

110 José Mas, "Don Quijote", Rojo y Gualda, año I, núm. 5 (22 de abril de 1916); "El hombre de las gafas negras", ibid., no. 28 (28 de octubre de 1916). El novelista Felipe Trigo y su trágica muerte también tuvieron eco en Rojo y Gualda, Felipe Trigo, "Fragmento de Sí sé por qué", ibid., núm. 22 (16 de septiembre de 1916); Constantino Cabal, "Tierra de encantamientos", ibid., núm. 25 (7 de octubre de 1916); Alfredo Nan de Allariz, "Causa y efecto", ibid., núm. 28 (28 de octubre de 1916); "Madrigal", ibid., año II, núm. 51 (7 de abril de 1917); Pedro de Répide, "Por encima de la muerte", ibid., año I, núm. 29 (4 de noviembre de 1916); "Perfiles españoles", ibid., núm. 31 (18 de noviembre de 1916).

111 Ramón Pérez de Ayala, "El asturiano fuera de Asturias", Rojo y Gualda, año I, núm. 12 (10. de julio de 1916); Alejandro Pérez Lugin, "Tierra gallega", ibid., núm. 14 (15 de julio de 1916); Elías Salaverría, "La fuerza de Vasconia", ibid., núm. 15 (22 de julio de 1916); Ricardo León, "Aires andaluces", ibid., núm. 10 (3 de junio de 1916); Eduardo Zamacois, "Aires asturianos", ibid., núm. 16 (29 de julio de 1916); Luis de Oteyza, "Cartas donostiarras", ibid., núm. 18 (19 de agosto de 1916).

${ }^{112}$ Luis Bonafoux, "Cositas de Europita", Rojo y Gualda, año I, núm. 6 (29 de abril de 1916); "El héroe, un señor y yo", ibid., núm. 9 (20 de mayo de 1916); "Desde Londres. Madres y lectores", ibid., núm. 20 (2 de septiembre de 1916); "El cascarón vacío", ibid., núm. 21 (9 de septiembre de 1916); "La sombra del ahorcado", ibid., núm. 23 (23 de septiembre de 1916); Julio Camba, "Desde Nueva York. El plátano como arma de conquista", ibid., núm. 20 (2 de septiembre de 1916); "Nueva York. El gran Prix electoral", ibid., núm. 26 (14 de octubre de 1916); "Norteamérica. Cachalotes, cocodrilos y millonarios", ibid., núm. 28 (28 de octubre de 1916); "Las famosas libertades americanas", ibid., núm. 31 (18 de noviembre de 1916); "El imperialismo financiero", ibid., núm. 36 (23 de diciembre de 1916). 
una publicación de temática amplia y plural en el marco de la comunidad migratoria que lo acogía, siguiendo muy de cerca la producción literaria y la edición de revistas culturales de la península. Al mismo tiempo, el empeño editorial de Florisel buscaba conceder a la colonia española un lugar en el espacio cultural mexicano y americano.

Su pretensión de recrear una identidad de origen entre sus compatriotas en México a partir de los temas clásicos de la intelectualidad expatriada como la lengua, la tradición cultural y literaria, la historia española y las costumbres y hábitos de la tierra de origen se plasmó en las páginas de Rojo y Gualda, la revista que se ha intentado "biografiar" en estas páginas.

La revista incluía firmas de inmigrantes periodistas conocidos en el pequeño círculo de los españoles de México, algunos con mucho tiempo en la profesión, otros recién llegados. Pero albergaba también, y de forma mayoritaria, textos publicados previamente en otras revistas, pertenecientes a escritores españoles afamados, aparte de algunas participaciones, más esporádicas, de poetas y ensayistas mexicanos y latinoamericanos consagrados, al igual que de españoles residentes en otros países americanos.

Los contenidos de Rojo y Gualda permiten pensar que la revista no era un producto periodístico más en el panorama de la prensa de la colonia española, que se conformaba con llenar sus números de folletines y noticias de toreros, futbolistas y tonadilleras, así como recrear su estrecho y a menudo conflictivo mundo asociativo. Sus páginas hablan de una selección cuidada de textos y de un conocimiento amplio de la cultura de habla hispana a ambos lados del Atlántico. Hablan de un intelectual culto y de una revista de enorme calidad, inmerecidamente olvidados.

\section{Referencias}

Albuerne, José. "Editorial". Rojo y Gualda, año II, núm. 70 (8 de agosto de 1917). Albuerne, José. "Mi despedida". Rojo y Gualda, año IV, núm. 144 (18 de enero de 1919).

Alcázar, Ricardo de [Florisel]. El cetro, las cruces y el caduceo (en busca de la conciencia de la colonia). México: Imprenta de Manuel León Sánchez, 1928.

Alcázar, Ricardo de [Florisel]. Cómo hablamos en México (Sintaxis sin tasa oral y escrita cogida al vuelo). México: Costa-Amic, 1944.

Alcázar, Ricardo de [Florisel]. El cuento y la cuenta del oro de América. México: Imprenta de Manuel León Sánchez, 1927. 
Alcázar, Ricardo de [(Florisel]. Donaire. México: La Voz Nueva, 1931.

Alcázar, Ricardo de [Florisel]. Epistolario de amor y de amistad. México: Tipografía "La Voz de la Verdad", 1939.

Alcázar, Ricardo de [Florisel]. El gachupín. Problema máximo de México. México: El Ideal, 1934.

Alcázar, Ricardo de [Florisel]. Ofrenda al silencio (arrepentimiento de Donaire). Madrid: Editorial Talleres Espasa Calpe, 1931.

Alcázar, Ricardo de [Florisel]. Por el alma y el habla de Castilla. Prólogo de Felipe Sassone. México: "El Día Español”, 1922.

Alcázar, Ricardo de [Florisel]. Unión, fusión y confusión de la colonia (un esquema de superestructura racional). México: Imprenta de Manuel León Sánchez, 1928.

Bada, Juan José. Ricardo de Alcázar (Florisel). Bosquejo biográfico y crítico. México: s. p. i., 1951.

Camín, Alfonso. "Mi despedida". Rojo y Gualda, año V, núm. 210 (1o. de mayo de 1920).

Camín, Alfonso. "Yo dije ayer". Rojo y Gualda, año IV, núm. 144 (18 de enero de 1919).

Cano Andaluz, Aurora. Historia de la Cámara Española de Comercio en México. México: Santillana, 2009.

Caudet, Francisco. El exilio republicano en México. Las revistas literarias (19391971). Madrid: Fundación Banco Exterior, 1992.

Editorial. "Don Quijote y Castillos y Leones". Castillos y Leones, año III, núm. 29 (23 de enero de 1922).

Elizalde, Lydia. El Correo Español. Aportes a la prensa periódica en México (1889-1898). México: Bonilla Artigas Editores, 2016.

"Florisel. Un treviense ilustre". Casino Español de México. Boletín Informativo 10 (mayo-agosto de 2005): 21-22.

Franco, Payo. "Se van Villaespesa y Mediz Bolio". El Nacional, ca. 1917.

García, Telésforo. "A Ricardo de Alcázar y compañeros de labor española". Rojo y Gualda, año I, núm. 1 (25 de marzo de 1916).

García, Telésforo. "La palabra del abuelo". Rojo y Gualda, año I, núm. 47 (10 de marzo de 1917).

García Sebastiani, Marcela. "La eficacia de las redes y los resultados de los vínculos: las élites de los inmigrantes españoles en la Argentina (18621923)". Revista Complutense de Historia de América 31 (2011): 147-176. 
García Sebastiani, Marcela. "Nacionalismos e identidad nacional entre los españoles en Argentina". En Hacer patria lejos de casa. Nacionalismo español, migración y exilio en Europa y América (1870-2010). Edición de Marcela García Sebastiani y Xosé M. Núñez Seixas, 41-71. Zaragoza: Prensas Universitarias de Zaragoza, 2020.

García Sebastiani, Marcela y Xosé M., Núñez Seixas, coordinadores. Hacer patria lejos de casa. Nacionalismo español, migración y exilio en Europa y América (1870-2010). Zaragoza: Prensas de la Universidad de Zaragoza, 2020.

García-Sedas, Pilar. Humberto Rivas Panedas. El gallo viene en aeroplano. Poemas y cartas mexicanas. Madrid: Renacimiento, 2009.

Garciadiego, Javier. "La prensa durante la Revolución mexicana". En Las publicaciones periódicas y la historia de México. Edición de Aurora Cano Andaluz, 71-88. México: Universidad Nacional Autónoma de México, 1995.

Gil Lázaro, Alicia. Inmigración y retorno. Españoles en la Ciudad de México, 1900-1936. Madrid: Marcial Pons / Universidad de Alcalá, Instituto de Estudios Latinoamericanos, 2015.

Gil Lázaro, Alicia. "Prensa étnica e inmigración. El periodismo español en México en el primer tercio del siglo XX". Revista Internacional de Historia de la Comunicación, núm. 9 (2017): 37-64.

Gil Lázaro, Alicia. "La Voz Nueva. El sueño editorial de Ricardo de Alcázar (19271932)". En Las migraciones europeas a América Latina. Nuevas perspectivas socioculturales a través del estudio de la prensa. Edición de Juan Andrés Bresciano, 9-43. Montevideo: Universidad de la República, Centro de Estudios Interdisciplinarios, Facultad de Humanidades y Ciencias de la Educación, 2021.

González Neira, Ana. Prensa del exilio republicano, 1936-1977. Santiago de Compostela: Andavira Editora, 2012.

Gracia Noriega, José Ignacio. "Ceferino Martínez Riestra: un escritor". Entrevista. Acceso el 30 de abril de 2021. http://www.llanes.as/nor/nie/2002 1014.htm.

Gutiérrez Domínguez, Mar. "Tensiones y conflictos entre los españoles en la Ciudad de México. Negocios, política, prensa y sociedad (1867-1914)". Tesis de doctorado. El Colegio de México, 2021.

Gutiérrez Hernández, Adriana. "Anselmo de la Portilla, La Iberia y el Casino Español (1867-1876)". En Españoles en el periodismo mexicano, siglos XIX y XX. Compilación y edición de Pablo Mora y Ángel Miquel, 75-90. México: 
Universidad Nacional Autónoma de México, Instituto de Investigaciones Bibliográficas / Universidad Autónoma del Estado de Morelos / Fundación Carolina, 2008.

MacGregor, Josefina. Revolución y diplomacia: México y España, 1913-1917. México: Instituto Nacional de Estudios Históricos de la Revolución Mexicana, 2002.

Maria y Campos, Armando de. Reseña histórica del periodismo español en México, 1821-1932. México: Cía. Editora, Distribuidora de Ediciones, S. A., 1960.

Martínez de Bujanda, Francisco. "Una carta". Rojo y Gualda, año I, núm. 2 (1o. de abril de 1916).

Meyer, Lorenzo. El cactus y el olivo. Las relaciones de México y España en el siglo XX. Una apuesta equivocada. México: Océano, 2001.

Miquel, Ángel. "Presentación [s. XX]" a Españoles en el periodismo mexicano, siglos XIX y XX. Compilación y edición de Pablo Mora y Ángel Miquel, 193196. México: Universidad Nacional Autónoma de México, Instituto de Investigaciones Bibliográficas / Universidad Autónoma del Estado de Morelos / Fundación Carolina, 2008.

Miquel, Ángel, Jesús Nieto Sotelo y Tomás Pérez Vejo, compiladores. Imágenes cruzadas. México y España, siglos XIX y XX. México: Universidad Autónoma del Estado de Morelos, 2005.

Mora, Pablo. "Presentación [s. XIX]" a Españoles en el periodismo mexicano, siglos XIX y XX. Compilación y edición de Pablo Mora y Ángel Miquel, 15-19. México: Universidad Nacional Autónoma de México, Instituto de Investigaciones Bibliográficas / Universidad Autónoma del Estado de Morelos / Fundación Carolina, 2008.

Mora, Pablo. "Telésforo García: articulista y polemista en El Centinela Español". En Españoles en el periodismo mexicano, siglos XIX y XX. Compilación y edición de Pablo Mora y Ángel Miquel, 123-128. México: Universidad Nacional Autónoma de México, Instituto de Investigaciones Bibliográficas / Universidad Autónoma del Estado de Morelos / Fundación Carolina, 2008.

Mora, Pablo y Ángel Miquel, editores. Españoles en el periodismo mexicano, siglos XIX y XX. México: Universidad Nacional Autónoma de México, Instituto de Investigaciones Bibliográficas / Universidad Autónoma del Estado de Morelos / Fundación Carolina, 2008. 
Navarro Azcue, Concepción y Gustavo H. Prado, editores. Intellectualism and Migration. International Networks of Europeans Culture in America (19th 21st Centuries). Charleston: Global South, 2016.

Navarro Azcue, Concepción y Julio Mesa Yanes. "Dossier: prensa y emigración española en América". Revista Internacional de Historia de la Comunicación 12 (2019): 8-15. DOI: 10.12795/RiHC. 2019.i12.01.

Ordóñez Alonso, María M. "El exilio republicano español y su aportación a la prensa y periodismo en México". Laberintos: Revista de Estudios sobre los Exilios Culturales Españoles, núm. 13 (2011): 113-122.

Pascual Gay, Juan. "Alfonso Camín y su Antología de poetas mexicanos (1929)". Revista de El Colegio de San Luis III, núm. 6 (julio-diciembre de 2013): 12-31.

Pérez de la Dehesa, Rafael. El grupo "Germinal": una clave del 98. Madrid: Taurus, 1970.

Perrín, Tomás G. "Programa espiritual de la Unión Española". Rojo y Gualda, año I, núm. 37 (30 de diciembre de 1916).

Rojo y Gualda, año I, núm. 1 - año V, núm. 223 (25 de marzo de 1916-1o. de septiembre de 1920).

Sánchez Andrés, Agustín y Pedro Pérez Herrero, editores. Historia de las relaciones entre España y México, 1821-2014. Madrid: Marcial Pons / Universidad de Alcalá, Instituto de Estudios Latinoamericanos, 2015.

Sánchez Andrés, Agustín, Tomás Pérez Vejo y Marco A. Landavazo, coordinadores. Imágenes e imaginarios sobre España en México, siglos XIX y XX. Morelia: Porrúa / Universidad Michoacana de San Nicolás de Hidalgo, Instituto de Investigaciones Históricas / Consejo Nacional de Ciencia y Tecnología, 2006.

Sánchez Illán, Juan Carlos, dirección. Diccionario biográfico del exilio español de 1939: los periodistas. Madrid: Fondo de Cultura Económica, Cátedra del Exilio, 2011.

Serna, Ana María. "Periodismo, Estado y opinión pública en los inicios de los años veinte (1919-1924)". Secuencia. Revista de Historia y Ciencias Sociales, núm. 68 (2007): 57-85. Acceso el 30 de abril de 2021. https://doi. org/10.18234/secuencia.v0i68.1005.

Serna, Ana María. "Prensa y sociedad en las décadas revolucionarias (19101940)". Secuencia. Revista de Historia y Ciencias Sociales, núm. 86 (2014): 109-149.

Sesto, Julio. "Larga crónica de un largo viaje". Tricolor, núm. 11 (abril de 1918). 
Sinningen, John H. "La presencia de la obra de Benito Pérez Galdós en la prensa mexicana". En Españoles en el periodismo mexicano, siglos XIX y XX. Compilación y edición de Pablo Mora y Ángel Miquel, 181-189. México: Universidad Nacional Autónoma de México, Instituto de Investigaciones Bibliográficas / Universidad Autónoma del Estado de Morelos / Fundación Carolina, 2008.

Suárez, Albino. "Alfonso Camín, Asturias y España: centenario de su nacimiento". Boletín del Instituto de Estudios Asturianos 45, núm. 137 (1991).

Villaurrutia, Xavier. "Traduciendo a Paul Valéry". En Textos y pretextos. México: Universidad Nacional Autónoma de México, 1940. «bg 